\title{
Agent-Based Modeling of Immune Response to Study the Effects of Regulatory $T$ Cells in Type 1 Diabetes
}

\author{
Qian Xu ${ }^{1}$, Mustafa Cagdas Ozturk ${ }^{2}$ and Ali Cinar ${ }^{1,2, *}$ \\ 1 Department of Biomedical Engineering, Illinois Institute of Technology, Chicago, IL 60616, USA; \\ qxu25@hawk.iit.edu \\ 2 Department of Chemical and Biological Engineering, Illinois Institute of Technology, Chicago, IL 60616, USA; \\ cagdasozturk@gmail.com \\ * Correspondence: cinar@iit.edu; Tel.: +1-312-567-3042
}

Received: 27 June 2018; Accepted: 21 August 2018; Published: 27 August 2018

\begin{abstract}
Regulatory $\mathrm{T}$ cells (Tregs) have an important role in self-tolerance. Understanding the functions of Tregs is important for preventing or slowing the progress of Type 1 Diabetes. We use a two-dimensional (2D) agent-based model to simulate immune response in mice and test the effects of Tregs in tissue protection. We compared the immune response with and without Tregs, and also tested the effects of Tregs from different sources or with different functions. The results show that Tregs can inhibit the proliferation of effector $\mathrm{T}$ cells by inhibiting antigens presenting via dendritic cells (DCs). Although the number and function of Tregs affect the inhibition, a small number of Tregs compared to $\mathrm{CD} 4^{+} \mathrm{T}$ cells can effectively protect islets in pancreatic tissue. Finally, we added Tregs to the system in the middle phase of the immune response. The simulation results show that Tregs can inhibit the production of effector $\mathrm{CD} 8^{+} \mathrm{T}$ cells and maintain a good environment for $\beta$ cell regeneration.
\end{abstract}

Keywords: Type 1 Diabetes; agent-based modeling; regulatory $\mathrm{T}$ cells; dendritic cells; $\mathrm{CD} 8^{+} \mathrm{T}$ cells; $\mathrm{CD}^{+} \mathrm{T}$ cells; $\alpha$ cells

\section{Introduction}

Type 1 Diabetes (T1D) is caused by auto-immune deficiency, where cell tolerance to auto-antigen is damaged, and leads to tissue destruction by the self-immune system. In the immune system, regulatory T cells (Tregs) and other tolerogenic cells play a key role in self-tolerance [1,2]. The balance in the number and function of Tregs and destructive $\mathrm{T}$ cells affects the results of the immune response [3,4]. Currently, many therapies developed for T1D focus on Tregs intervention [5-7]. Therefore, investigating the relationship between Tregs and other immune system components is important in preventing or slowing the progress of auto-immune disease.

Computational modeling can be used to assess rapidly the potential performance of new therapies and treatment under development. Computational models of T1D with different goals have been developed [8,9]. Besides economic models [10] and glucose-insulin models [11], models that describe the autoimmune pathogenesis of T1D were also proposed [12-14]. Shoda et al. developed a relatively complex mathematical model describing the dynamics of immune response [12]. Wedgwood et al. built a multiscale model combining ordinary differential equations (ODE) and agent-based modeling in simulating interactions among $\beta$ cells, $\mathrm{T}$ cells and B cells [14]. Agent-based modeling (ABM) can simulate behaviors and interactions of individual entities, and offers flexibility in simulating heterogeneous interactions and complex individual behaviors which can be characterized by if-then rules and thresholds. It also provides a framework that can easily adjust the size and complexity of a system through adding new agents and rules of behaviors or interactions [15]. 
In our previous work, we developed an ABM to simulate the interactions between $\beta$ cell and $\mathrm{CD} 8^{+} \mathrm{T}$ cells in pancreatic tissue of mice [16]. In this work, we further developed the ABM of disease progression within the pancreatic lymph node and tissue in mice. By describing the activities of Tregs and dendritic cells (DCs), the model estimates the effect of Tregs in achieving cell tolerance and protecting islets.

\section{The Model}

The model developed extends our previous model [16] built by using the Repast High Performance Computing (HPC) toolkit [17]. It is composed of cell agents, rules of cell behaviors, environments for interactions of cell agents with each other and their environments. As with previous work, the model is two-dimensional (2D) and the time resolution is $1 \mathrm{~min}$. Simulation starts from 3-week age of mice to 14-week age of mice, lasting for 11 weeks. The model has two "spaces" of $200 \times 200$ grids representing pancreatic tissue $(10 \mu \mathrm{m} / \mathrm{grid})$ and pancreatic lymph node (PLN, $15 \mu \mathrm{m} /$ grid), respectively. The cell agents in this model include $\beta$ cells, $\alpha$ cells, dendritic cells (DCs), CD8 ${ }^{+} \mathrm{T}$ cells, $\mathrm{CD}^{+} \mathrm{T}$ cells and regulatory T cells (Tregs). The $\beta$ cells, $\alpha$ cells and Basement Membrane (BM) constitute the islets which are dispersed in the pancreatic tissue space (Figure 1). The parameters of cell agents are listed in Table 1. The behaviors of cells and the rules of cell agents in the model are presented in Sections 2.1-2.5. The schematic diagram of cell interactions in pancreatic lymph node (PLN) and pancreatic tissue is displayed in Figure 2, and a flowchart of agent behavior is given in Figure 3. The parameters and the rules of cell behaviors are based on information from the literature cited in references.

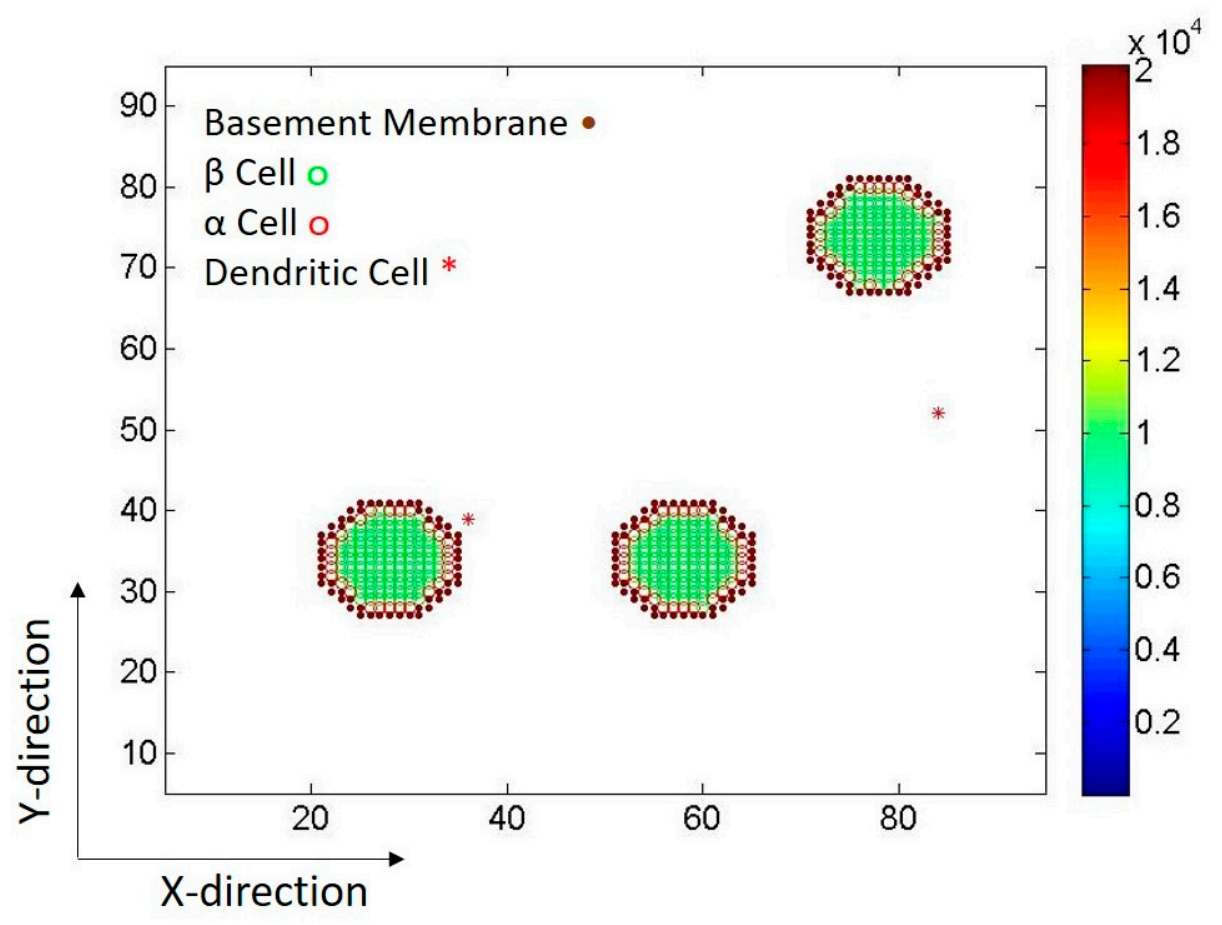

Figure 1. Islet cell arrangement in two-dimensional space grid. $\alpha$ cells (red circle) surround $\beta$ cells (green circle) and Basement Membrane (BM) (brown dot) encloses all the cells. Islets present core-mantle structure. Color bar shows strength value of BM during disease progression during a simulation. 
Table 1. The parameters of spaces and cell agents.

\begin{tabular}{|c|c|c|c|c|c|c|}
\hline \multirow{2}{*}{ Cells/Micro-Organ } & \multirow{2}{*}{$\begin{array}{c}\text { Initial } \\
\text { Amount } 1\end{array}$} & \multicolumn{2}{|c|}{ Lifespan (Days) } & \multicolumn{2}{|c|}{ Move Speed $(\mu \mathrm{m} / \mathrm{min})$} & \multirow{2}{*}{$\begin{array}{l}\text { Proliferation Rate } \\
\text { (hours/cell) }\end{array}$} \\
\hline & & Effector & Naive & PLN $^{2}$ & Tissue & \\
\hline $\mathrm{CD}^{+}{ }^{+} \mathrm{T}$ cells & 1576 & $6[18]$ & 27 [19] & $15^{3}[20]$ & 10 & 36 \\
\hline $\mathrm{CD}^{+} \mathrm{T}$ cells & 676 & $6[21]$ & 70 [19] & 15 [22] & $10[22]$ & $\sim 14.3[23]$ \\
\hline DCs & 6 & $3 \mathrm{~d}$ in $\mathrm{PI}$ & {$[24,25]$} & 7.5 & $5[26]$ & / \\
\hline Tregs & 176 & $5 \mathrm{~d}$ & $61[27]$ & $15[20]$ & 10 & $36[28]$ \\
\hline$\beta$ cells / islets & $\sim 1100 / 11$ & \multicolumn{2}{|c|}{ / } & \multicolumn{2}{|c|}{ / } & $42^{4}[29]$ \\
\hline
\end{tabular}

${ }^{1}$ The amount proportionally reduced according to $[19,30-32] ;{ }^{2}$ Pancreatic lymph node. ${ }^{3} 2 \mu \mathrm{m} / \mathrm{min}$ less than Tregs [20], to simplify model we set same speed with Tregs; ${ }^{4}$ Adjust cell-cycle to satisfy that islet can recover within 2 weeks.

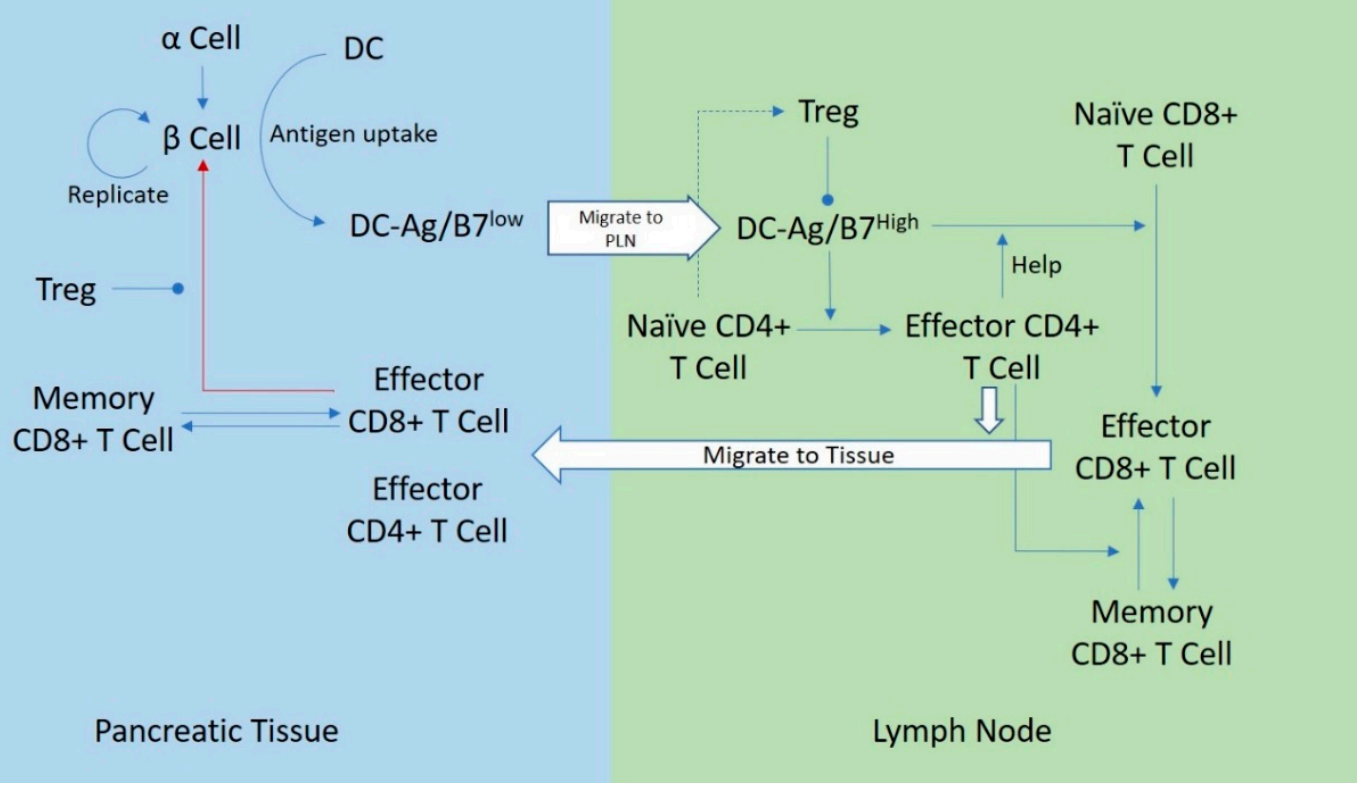

Figure 2. Schematic diagram of cell interactions in pancreatic lymph node (PLN) and pancreatic tissue in the agent-based modeling (ABM). In the beginning, DCs take up antigen from $\beta$ cells and then migrate to lymph node. Meanwhile, they produce more B7 and go to maturation. Then, mature dendritic cells (DCs) activate naive $\mathrm{CD} 4^{+} \mathrm{T}$ cells which subsequently differentiated into effector $\mathrm{CD} 4^{+} \mathrm{T}$ cells. With the help of the effector $\mathrm{CD} 4^{+} \mathrm{T}$ cells, mature DCs can activate naive CD8 ${ }^{+} \mathrm{T}$ cells (These DCs are called 2nd mature DCs in this model). Similarly, when the memory CD8 ${ }^{+} \mathrm{T}$ cell are activated, they need the help of effector $\mathrm{CD} 4^{+} \mathrm{T}$ cells. These effector $\mathrm{CD} 4^{+}$and $\mathrm{CD} 8^{+} \mathrm{T}$ cells would migrate to pancreatic tissue after several proliferations. In pancreatic tissue, the effector $\mathrm{CD}^{+} \mathrm{T}$ cells kill $\beta$ cells. In response, $\beta$ cells start to replicate and $\alpha$ cells also convert to $\beta$ cells. Regulatory T cells (Tregs) can downregulate B7, induce $\mathrm{CD}^{+} \mathrm{T}$ cell to Tregs by secreting molecules, and inhibit $\mathrm{CD} 8^{+} \mathrm{T}$ cell function directly. 

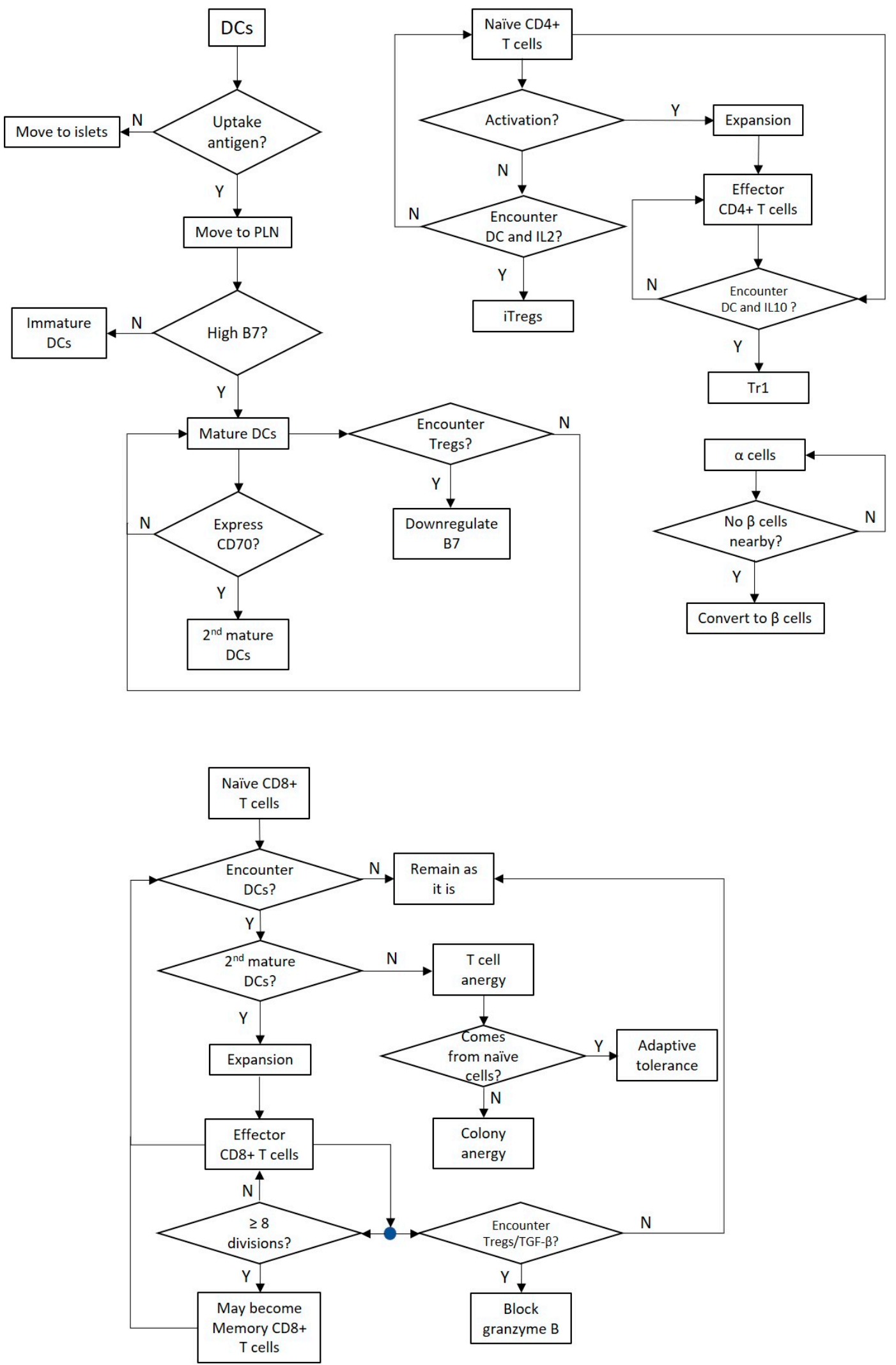

Figure 3. The flow chart of cell agent behaviors. 


\subsection{Islets of Langerhans}

New $\beta$ cells are generated from three sources during the progression of T1D: non- $\beta$ cell precursors (such as the duct epithelium), existing $\beta$ cells, and $\alpha$ cells [33]. In mice, $\alpha$ cells transdifferentiate to $\beta$ cells upon Pax4 ectopic expression [34] with or without cell division [29]. In this model, $\beta$ cell self-renewal and $\alpha$ cell conversion were implemented. Within two weeks [29], the islets in the model, whose $\beta$ cells were almost destroyed, are composed of neogenic $\beta$ cells and almost reach the original number of $\beta$ cells if no destructive lymphocytes exist in pancreatic tissue. The mouse islets present a core-mantle arrangement of $\alpha$ cells and $\beta$ cells [35]. In this model, the $\alpha$ cells enclose $\beta$ cells and account for $\sim 20 \%$ of islets cells (Figure 1 ).

\subsection{Dendritic Cells}

Dendritic cells are one of the antigen-presenting cell types. DCs can be recruited to islets by monocyte chemoattractant protein (MCP) and macrophage inflammatory protein (MIP), which are secreted by $\beta$ cells, endothelial cells, macrophages, DCs and lymphocytes [36-38]. The immature DCs in this model move toward the nearest islet, stop and secrete molecules to dissolve Basement membrane (BM) when they encounter it. After the BM is dissolved, they invade the islet and contact $\beta$ cells.

After uptake of antigen, DCs migrate to lymph nodes through the afferent lymph [39], gradually go to maturation [40], and stimulate $\mathrm{CD} 4^{+}$and $\mathrm{CD} 8^{+} \mathrm{T}$ cells with/without the presence of regulatory T cells (Tregs) [24,41,42]. Lymphatic vessels are always located near blood vessels and close to the islets in mouse model and humans [36,43]. DCs migrate to lymphatic vessels through responding to the gradient of CCR7 ligands [44]. In steady-state tissue, the uptake of self-antigen by DCs can cause tolerance of autoreactive cells; in inflammation, they induce effector T cells [42]. The expression of costimulatory molecules on DCs is important for activation of T cells (both CD4 ${ }^{+}$ and $\mathrm{CD}^{+} \mathrm{T}$ cell) $[45,46]$. Mature DCs express a high level of costimulatory molecules such as CD80/86 (B7-1/B7-2) and CD40, and produce IL-12 [40], while Tregs can downregulate CD80/86 on DCs to inhibit their maturation [47]. The CD27/CD70-interaction is important for priming CD8 ${ }^{+} \mathrm{T}$ cells [46,48]. The CD27 is expressed on CD8 ${ }^{+} \mathrm{T}$ cells while the CD70 is expressed by DCs under the help of $\mathrm{CD} 4^{+} \mathrm{T}$ cells [49]. Therefore, only the mature DCs can activate $\mathrm{CD} 4^{+} \mathrm{T}$ cells and the mature DCs with the help of $\mathrm{CD} 4^{+} \mathrm{T}$ cells can successfully activate $\mathrm{CD} 8^{+} \mathrm{T}$ cells (Figure 2 ). The number of DCs in pancreatic tissue was kept constant in the early period of islet destruction and moderately increased in the later period (Table 2).

Table 2. The number of DCs in pancreatic tissue.

\begin{tabular}{ccccc}
\hline Week & $\mathbf{3 \sim 9}$ & $\mathbf{9 \sim 1 0}$ & $\mathbf{1 0 ~ 1 2}$ & $\mathbf{1 2 ~ 1 4}$ \\
\hline DC number (cell) ${ }^{1}$ & 6 & 68 & 136 & 170 \\
\hline \multicolumn{5}{c}{ Calculated approximately from [30]. }
\end{tabular}

\section{3. $\mathrm{CD} 8^{+} \mathrm{T}$ Cells}

$\mathrm{CD}^{+} \mathrm{T}$ cells can kill $\beta$ cells via direct contact or cytokine secretion [50] under complete activation. Their killing ability (55\%), motility pattern (random walk) and proliferation behavior (naïve $\mathrm{T}$ cell $\rightarrow$ effector T cell $\rightarrow$ memory T cell) are similar to our previous model [16]. CD8 ${ }^{+} \mathrm{T}$ cell activation occurs in pancreatic lymph node. When their activation is not complete (i.e., when they encounter DCs with low costimulatory molecules), they go to anergy [51]. Activated T cells with clonal anergy are inhibited in their proliferation but maintain their destructive function on $\beta$ cells, while naïve T cells with adaptive tolerance reduce their proliferation rate and weaken their killing ability [51] (Table 3). Besides, the complete activation of memory cells also needs the help of costimulatory molecules. 
If memory cells are not completely activated, their progenies would lose their ability to survive under second stimulation [52].

Table 3. Properties of anergic T cell [51,52].

\begin{tabular}{|c|c|c|c|c|}
\hline Type & Affected Cell & Effector Function & Proliferation & Reactivation \\
\hline Clonal anergy & Activated T cell & Normal & Inhibited & / \\
\hline \multirow{2}{*}{$\begin{array}{l}\text { Adaptive } \\
\text { tolerance }\end{array}$} & \multirow{2}{*}{ Naïve T cell } & \multirow{2}{*}{$\begin{array}{c}\text { Reduce killing } \\
\text { probability to } 10 \%\end{array}$} & \multirow{2}{*}{$\begin{array}{l}3 \text { times longer cell } \\
\text { cycle }\end{array}$} & Persist under strong stimulation \\
\hline & & & & Death under weak stimulation \\
\hline
\end{tabular}

\section{4. $C D 4^{+}$T Cells}

$\mathrm{CD}^{+}$helper $\mathrm{T}$ cells (Th cells) help CD8 ${ }^{+} \mathrm{T}$ cell activation via CD40 pathway $[48,49,52,53] . \mathrm{CD}^{+} \mathrm{T}$ cells express CD40L which can bind to CD40 on DCs [54], and then DCs are induced to express CD70 [49] which affect CD8 ${ }^{+} \mathrm{T}$ cell responses [48]. Besides, IL-2 secreted by CD4 ${ }^{+} \mathrm{T}$ cells is needed in iTregs conversion [55].

Tregs with $\mathrm{CD}^{+}$Foxp3 $^{+} /$Foxp3 $^{-}$can inhibit inflammation through many pathways, such as targeting DCs, secreting inhibitory cytokines, and producing Granzyme B/A to kill effector T cells directly [56]. In this model, several pathways were implemented (Figure 2). First, the killing capacity of $\mathrm{CD}^{+} \mathrm{T}$ cells can be inhibited by contacting Tregs within the presence of Transforming Growth Factor- $\beta$ (TGF- $\beta$ ) [57]. Secondly, Tregs downregulate the expression of B7 on the surface of DCs [47] and maintain immaturity of DCs [58]. Third, IL-10 which is secreted by Tregs can induce naïve CD4 ${ }^{+}$ $\mathrm{T}$ cells and destructive CD4 ${ }^{+} \mathrm{T}$ cells to differentiate into induced-Tregs (iTregs) or Foxp3 ${ }^{-} \mathrm{IL}^{-10^{+}}$ regulatory Type-1 T cells $(\operatorname{Tr} 1)$ [41].

Natural regulatory $T$ cells (nTregs) mature in thymus while iTregs differentiate from naïve CD4 ${ }^{+}$ T cells $[41,59,60]$. iTregs is induced from naïve $\mathrm{CD}^{+} \mathrm{T}$ cells under the presence of TGF- $\beta$ and IL-2 [55]. In this model, we assume that there is enough TGF- $\beta$ in the environment. Besides, $\operatorname{Tr} 1$ can be induced from $\mathrm{CD}^{+} \mathrm{T}$ cells under the presence of IL-10 [61]. In this model, the Tregs include nTregs and iTregs (including Tr1) (Table 4). Tregs can also migrate into pancreatic tissue [27,62].

Table 4. IL-10 producing (activated) Treg sources [41].

\begin{tabular}{cc}
\hline Sources & Condition \\
\hline nTregs & Dendritic cell (DC) with strong B7 \\
\hline Naive CD4 ${ }^{+}$T cells & Step 1 DC with weak B7 and IL-2 \\
\cline { 2 - 2 } & Step 2 DC with strong B7 \\
\hline Naive CD4 ${ }^{+}$T cells & DC with strong B7 and IL-10 \\
\hline Effector CD4 ${ }^{+}$T cells & DC with strong B7 and IL-10
\end{tabular}

\subsection{Compartments}

Pancreatic lymph node (PLN): Antigen presentation to T cells first happens in PLN. This process involves different cell types and complex control (Figures 2 and 3). nTregs exist in homeostasis and would expand themselves under the presence of DCs with high B7 (DCs-B7 ${ }^{\text {high }}$ ). Activated Tregs migrate to DCs-B7 ${ }^{\text {high }}$ and then downregulate B7 expression, inhibiting DCs' maturation. Tregs can inhibit the killing ability of progenies of naïve $\mathrm{CD}^{+} \mathrm{T}$ cells and the proliferation of effector $\mathrm{T}$ cells through inhibition of DCs, which lead to T cell anergy. If DCs with antigen successfully obtain high $\mathrm{B} 7$, they would activate naïve $\mathrm{CD} 4^{+} \mathrm{T}$ cells which then differentiate and expand effector CD4 ${ }^{+} \mathrm{T}$ cells. These effector T cells help DCs-B7 ${ }^{\text {high }}$ secrete CD70. Then the DCs can activate CD8 ${ }^{+} \mathrm{T}$ cells.

$\mathrm{CD}^{+} \mathrm{T}$ cells can be activated by mature DCs with the help of CD4 ${ }^{+} \mathrm{T}$ cells and expand effector $\mathrm{CD}^{+} \mathrm{T}$ cells (Figures 2 and 3 ). However, if naïve $\mathrm{CD}^{+} \mathrm{T}$ cell activation occurs upon presence of IL-10 
(secreted by Tregs), they would differentiate to Tr1 (also secrete IL-10) [41]. After several proliferations, effector $\mathrm{CD}^{+}, \mathrm{CD}^{+} \mathrm{T}$ cells and Tregs would migrate to tissue.

Pancreatic tissue: $\beta$ cells can self-replicate when islets are under attack and $\alpha$ cells have the ability to convert to $\beta$ cells. These are sources of new $\beta$ cells during progression of disease. DCs take up antigen from islets in tissue and then migrate to lymph node, inducing adaptive immune response (Figure 2). Through TGF- $\beta$ pathway, Tregs can also inhibit the killing ability of effector T cells.

\section{Results}

This model was used for simulating disease progress in mice model from 3-week age to 14-week age with or without Tregs. In Figure 4 and subsequent figures, the x-axis shows the time (days) from the beginning of the simulation (week 3). We use box-and-whisker plots to present the dynamics of immune response. Each case was performed through 15 repeated simulations. Boxes cover data from the first quartile to the third quartile, and circles show the median and whiskers show the locations of the maximum and minimum values. The variations in data are caused by from stochastic variations such as cell motility and killing probability.
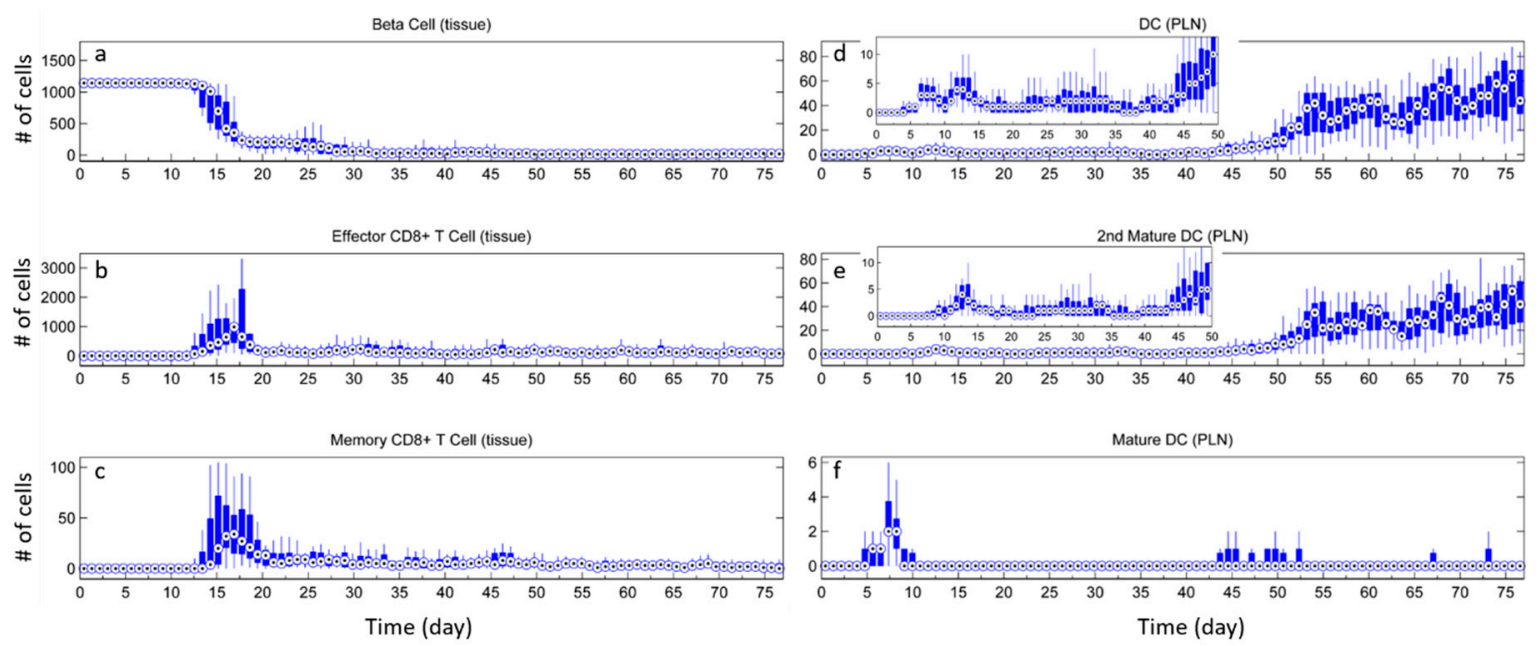

Figure 4. Simulation results for case without Tregs (case I). There are no initial Tregs and also no conversion ability of $\mathrm{CD}^{+} \mathrm{T}$ cells. The number of (a) $\beta$ cells, (b) effector $\mathrm{CD}^{+} \mathrm{T}$ cells, (c) memory $\mathrm{CD}^{+} \mathrm{T}$ cells- in pancreatic tissue are shown on the left column. The number of (d) total DCs, (e) 2nd mature DCs, (f) mature DCs in PLN are shown on the right column. Inserts (number of cells vs. time) show small change of cell number in the bottom figures. $t=0$ days correspond to 3-week age of mouse.

\subsection{Without Tregs}

Figures 4 and 5 depict the variation in different cells without Tregs in pancreatic tissue and in pancreatic lymph node. With the increase of effector $C D 8^{+} \mathrm{T}$ cells, the number of $\beta$ cells decrease starting from day 12 (Figure $4 a, b)$. After a sharp decrease, $\beta$ cells go to a gradually decreasing stage on day 18 when the number of effector $\mathrm{CD} 8^{+} \mathrm{T}$ cells decreases. Afterwards, the $\beta$ cell count shows a small fluctuation during the decrease as a result of $\beta$ cell regeneration and destructive function of $\mathrm{CD}^{+} \mathrm{T}$ cells. Memory $\mathrm{CD} 8^{+} \mathrm{T}$ cells descend from effector cells and can be reactivated to effector cells; therefore, they increase relatively later than effector $\mathrm{CD} 8^{+} \mathrm{T}$ cells and their numbers fluctuate.

Meanwhile, DCs which uptake antigen in pancreatic tissue migrate to lymph nodes. After maturation, they can stimulate the differentiation of naïve $\mathrm{CD} 4^{+} \mathrm{T}$ cells into effector $\mathrm{CD} 4^{+}$ $\mathrm{T}$ cells. Therefore, the number of effector $\mathrm{CD} 4^{+} \mathrm{T}$ cells (Figure $5 \mathrm{f}$ ) increases following the appearance of mature DCs (Figure 4f). The 2nd mature DCs represent mature DCs which were helped by effector $\mathrm{CD}^{+} \mathrm{T}$ cells and then can activate $\mathrm{CD}^{+} \mathrm{T}$ cells. Because in this model, the DCs which prefer to activate $\mathrm{CD}^{+} \mathrm{T}$ cells and the DCs which prefer to activate $\mathrm{CD} 8^{+} \mathrm{T}$ cells were represented by only one 
kind of DC agents, the 2nd mature DCs can also activate $\mathrm{CD} 4^{+} \mathrm{T}$ cells. The effector $\mathrm{CD} 8^{+} \mathrm{T}$ cells arise after day 10 (Figure 5b) after the emergence of 2nd mature DCs ( day 9) (Figure 4e). The number of memory CD8 ${ }^{+} \mathrm{T}$ cells in PLN goes up corresponding with the increase of effector CD8 ${ }^{+} \mathrm{T}$ cells. Although most of DCs are matured DCs, $C D 8^{+} \mathrm{T}$ cells with colony anergy still arise (Figure $5 \mathrm{~d}$ ) because of the large number of effector $\mathrm{CD} 8^{+} \mathrm{T}$ cells. The anergic $\mathrm{T}$ cells with adaptive tolerance increase near the beginning of simulation ( day 7) due to the larger number of naive $\mathrm{T}$ cells at that time (Figure $5 \mathrm{a}$ ).
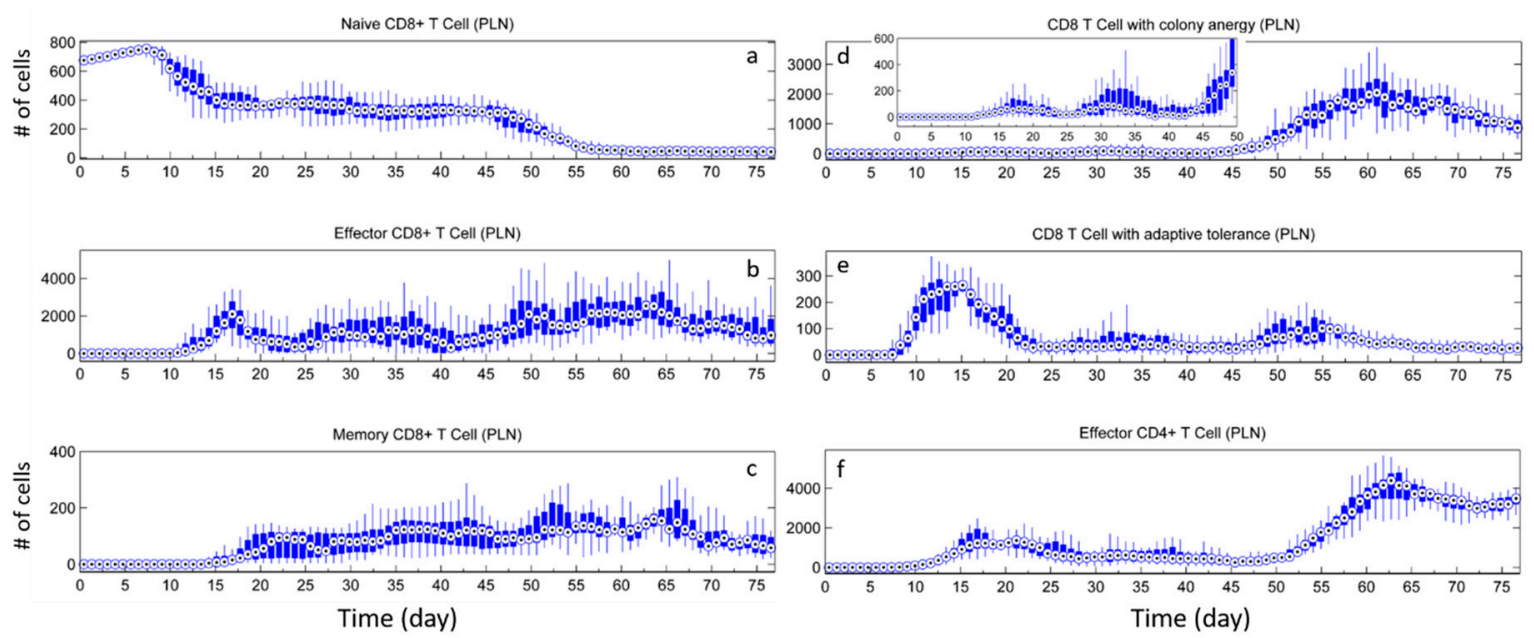

Figure 5. Simulation results for case without Tregs (case I). The number of (a) naive CD $8^{+} \mathrm{T}$ cells, (b) effector $\mathrm{CD}^{+} \mathrm{T}$ cells, (c) memory $\mathrm{CD}^{+} \mathrm{T}$ cells, (d) $\mathrm{CD}^{+} \mathrm{T}$ cells with colony anergy, (e) $\mathrm{CD} 8^{+} \mathrm{T}$ cells with adaptive tolerance, (f) effector $\mathrm{CD}^{+} \mathrm{T}$ cells in PLN are shown. Inserts (number of cells vs. time) show small change of cell number in the bottom figures. $t=0$ day corresponds to 3 -week age of mouse.

\subsection{Effect of Tregs}

Tregs usually account for $5-10 \%$ of $\mathrm{CD}^{+} \mathrm{T}$ cells in lymph node [32]. In this model, the number of initial Tregs added also accounts for $10 \%$ of $\mathrm{CD}^{+} \mathrm{T}$ cells at the beginning of simulation. Besides, Tregs also can be descended from naive $\mathrm{CD} 4^{+} \mathrm{T}$ cells or effector $\mathrm{CD} 4^{+} \mathrm{T}$ cells under certain conditions [41]. The effect of Tregs on the progression of diabetes is shown in Figures 6 and 7. In pancreatic tissue, $\beta$ cells were rarely attacked by effector $\mathrm{CD} 8^{+} \mathrm{T}$ cells. The number of effector $\mathrm{CD}^{+} \mathrm{T}$ cells (maximal median: 0; box: 0 340) in pancreatic tissue (Figure 6b) was much less than that (maximal median: 1000; box: 200 2000) in the case without Tregs (Figure 4b), and CD8 ${ }^{+} \mathrm{T}$ cells disappear after several weeks. In lymph nodes, following the rise of mature DCs in several phases (e.g., day 7 8, day 25 27, day 43 55) shown in Figure 6, the activated Tregs and effector CD4 ${ }^{+} \mathrm{T}$ cells increased (Figure 7e,f). The multiple waves of mature DCs observed in Figure $6 \mathrm{f}$ is related to the number of activated Tregs (Figure 7e). When the number of Tregs becomes small, the probability of increase in mature DCs is high. Also, the 2 nd mature DCs which can activate CD8 ${ }^{+} \mathrm{T}$ cells scarcely appear. Note that, effector CD8 $8^{+} \mathrm{T}$ cells in PLN arise on day 11 in several simulations, the 2nd mature DCs also appeared close to this time although they cannot be observed in the Figure 6. Day 45 55, the fact that the 2nd mature DCs increase but the effector $\mathrm{CD} 8^{+} \mathrm{T}$ cells cannot be observed may be attributed to the decreased naive $\mathrm{CD} 8^{+} \mathrm{T}$ cells and reduced encounter probability. With the presence of Tregs, the reduction in naive $\mathrm{CD} 8^{+} \mathrm{T}$ cells is consistent with increase of anergic $\mathrm{T}$ cells (Figure $7 \mathrm{a}, \mathrm{d}$ ); therefore, they primarily convert to anergic $\mathrm{T}$ cells in this scenario. 

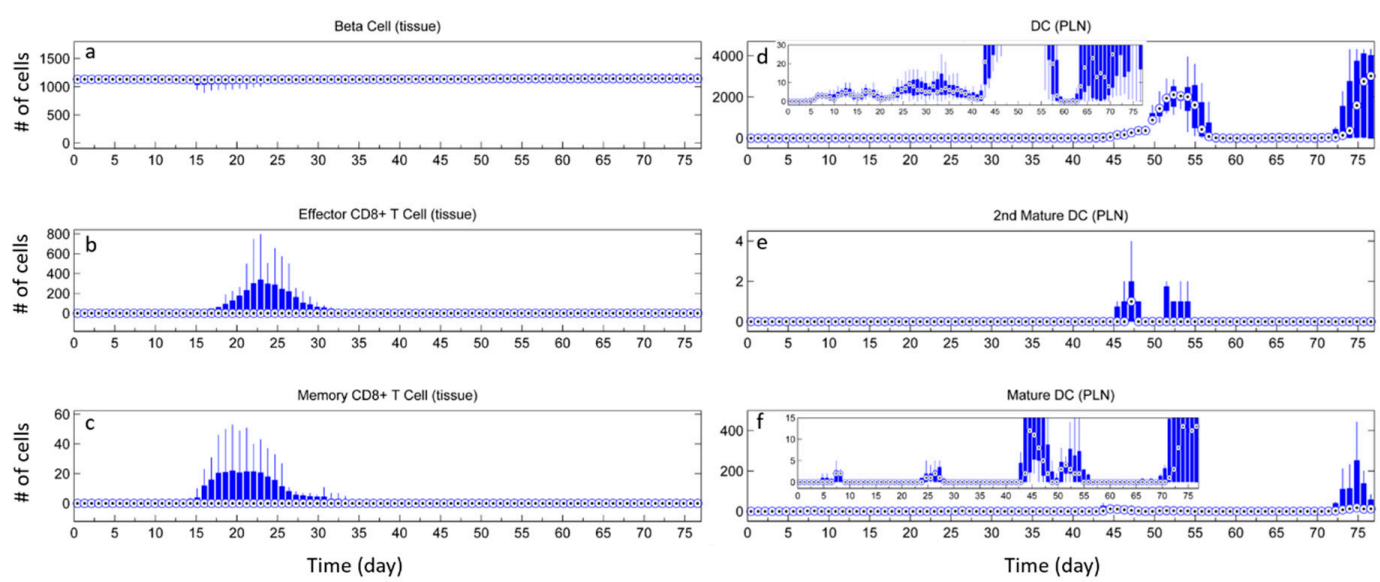

Figure 6. Simulation results for case with Tregs (case II). There are initial Tregs and conversion ability of $\mathrm{CD}^{+} \mathrm{T}$ cells. The number of (a) $\beta$ cells, (b) effector $\mathrm{CD} 8^{+} \mathrm{T}$ cells, (c) memory CD8 ${ }^{+} \mathrm{T}$ cells- in pancreatic tissue are shown on the left column. The number of (d) total DCs, (e) 2nd mature DCs, (f) mature DCs in PLN are shown on the right column. Inserts (number of cells vs. time) show small change of cell number in the bottom figures. $t=0$ day corresponds to 3-week age of mouse.
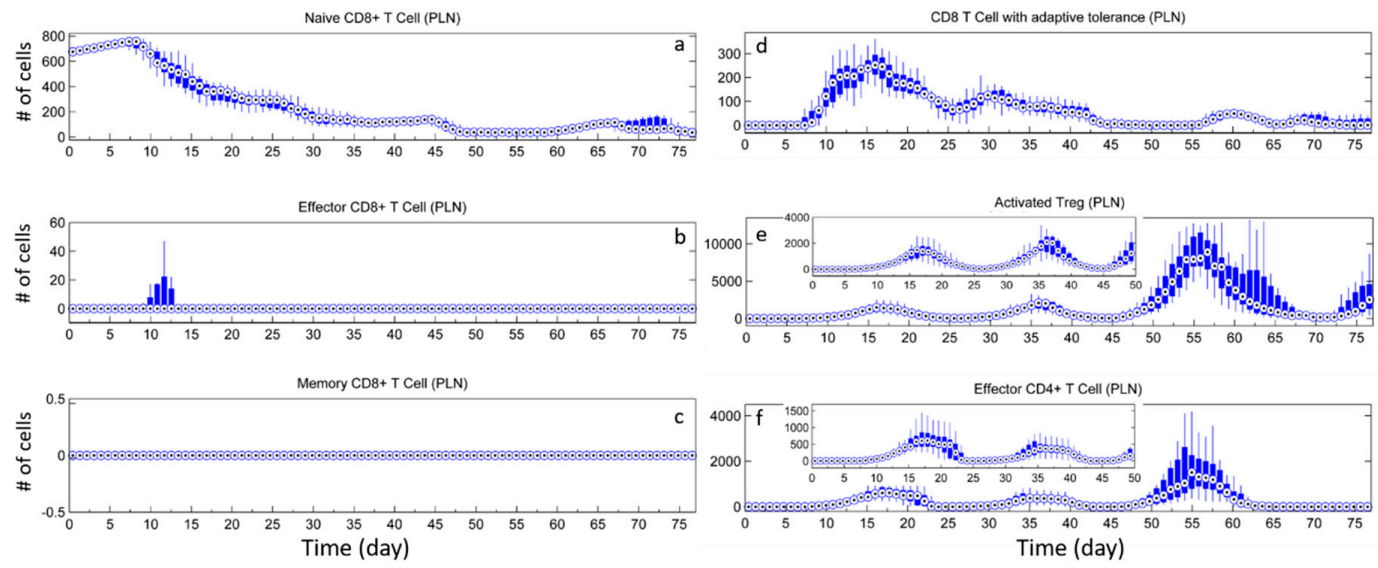

Figure 7. Simulation results for case with Tregs (case II). The number of (a) naive $\mathrm{CD} 8^{+} \mathrm{T}$ cells, (b) effector $\mathrm{CD}^{+} \mathrm{T}$ cells, (c) memory $\mathrm{CD} 8^{+} \mathrm{T}$ cells, (d) $\mathrm{CD} 8^{+} \mathrm{T}$ cells with adaptive tolerance, (e) activated Tregs, (f) effector $\mathrm{CD}^{+} \mathrm{T}$ cells in PLN are shown. Inserts (number of cells vs. time) show small change of number. $t=0$ day corresponds to 3 -week age of mouse.

\subsection{Effects of Tregs from Different Sources}

Tregs come from two sources: resident Tregs and induced Tregs from $\mathrm{CD} 4^{+} \mathrm{T}$ cells. To check their individual effect on immune response, we block one of them in specific simulations. We can observe that the results of the case with only resident Tregs (Figures A1 and A2 in Appendix A, case III) is similar to the case with both resident and induced Tregs (Figures 6 and 7, case II). This could be due to the number of Tregs satisfying the condition to inhibit the activation of $\mathrm{CD} 8^{+} \mathrm{T}$ cells. However, after day 50, the peak of activated Tregs is about 10,000 in case II and it is only 4500 in case III. This difference could contribute to the addition of induced Tregs. Note that, the effector CD4 ${ }^{+} \mathrm{T}$ cells show the 4th wave in the case without induced Tregs (Figure A2f), while there is no 4th wave in the case with induced Tregs (Figure 7f). This could be attributed to the possibility that induction of Tregs from $\mathrm{CD}^{+} \mathrm{T}$ cells reduce the probability of effector cell differentiation from $\mathrm{CD} 4^{+} \mathrm{T}$ cells. For the case with only induced Tregs (Figures A3 and A4), the effector CD8 ${ }^{+} \mathrm{T}$ cells first increase and kill $\beta$ cells, then Tregs converted from $\mathrm{CD} 4^{+} \mathrm{T}$ cells gradually increase. Tregs without activation appear first on approximately day 12 and keep a low level until day 40, and the activated Tregs first arise after day 
15. After day 45, the activated Tregs increase appreciably. The number of 2 nd mature DCs remains low on day 20 40 and day 47 77 which may be affected by Tregs. The increase in 2nd mature DCs on around day 45 could be due to the abrupt DC increase in tissue (Table 2), as well as the deficiency of activated Tregs at same time. And then, the production of effector $\mathrm{CD}^{+} \mathrm{T}$ cells are relatively inhibited and $\beta$ cells gradually recover (Figures A3 and A4).

Tregs inhibit immune response through two pathways in this model: inhibiting DCs to further inhibit $\mathrm{CD}^{+} \mathrm{T}$ cells and directly inhibiting $\mathrm{CD}^{+} \mathrm{T}$ cells' destructive function. The inhibition of DCs maturation would inhibit the effector T cells, while the direct inhibition by Tregs inhibit their killing ability. To test this effect on immune response, the inhibition through DCs was blocked. Figures A5 and A6 show the results. The effector $\mathrm{CD}^{+} \mathrm{T}$ cells increase in pancreatic tissue during day 12 35, leading to decrease of $\beta$ cell at the same time. The peak of effector $\mathrm{CD}^{+} \mathrm{T}$ cells appeared on day 25 , however, the $\beta$ cells on day 25 did not decrease. The reason is shown on Figure A6f, almost all effector $\mathrm{CD}^{+} \mathrm{T}$ cells in pancreatic tissue were inhibited directly by Tregs, and these deactivated cells cannot secrete granzyme to kill $\beta$ cells. The peaks of effector CD8 ${ }^{+} \mathrm{T}$ cells (Figures A5b and A6b) are relatively lower than the case without Tregs (Figures $4 b$ and $5 b$ ). In this case, Tregs lose the function of downregulating costimulatory molecules on DCs, but they remain capable of tracking DCs in a small area. The occupied space near DCs may reduce the contact probability between $\mathrm{CD} 4 / 8^{+} \mathrm{T}$ cells and DCs. $\beta$ cells decrease and finally recover, which shows downregulation of costimulatory molecules can partly prevent $\beta$ cell destruction.

\subsection{External Addition of Tregs}

Based on the first case, where no Tregs exist in PLN and tissue and the ability of CD4 ${ }^{+} \mathrm{T}$ cells conversion to Tregs is blocked, we add Tregs at 8-week age and let the Tregs keep the lowest level. And then we can observe that the 2nd mature DCs were inhibited (Figure 8e) accompanied with activated Tregs increase (Figure 9b). Similarly, effector $\mathrm{CD}^{+}{ }^{+} \mathrm{T}$ cells and effector $\mathrm{CD}^{+} \mathrm{T}$ cells were both inhibited after Tregs arise (Figure $5 b, f$ and Figure $9 c, d$ ). As a result, the $\beta$ cells in tissue recovered quickly and kept a relatively constant number during the rest of simulation (Figure 8a). Therefore, the Tregs added in the middle phase can successfully inhibit new effector $\mathrm{CD}^{+} \mathrm{T}$ cell production and keep a protective environment for $\beta$ cell regeneration.
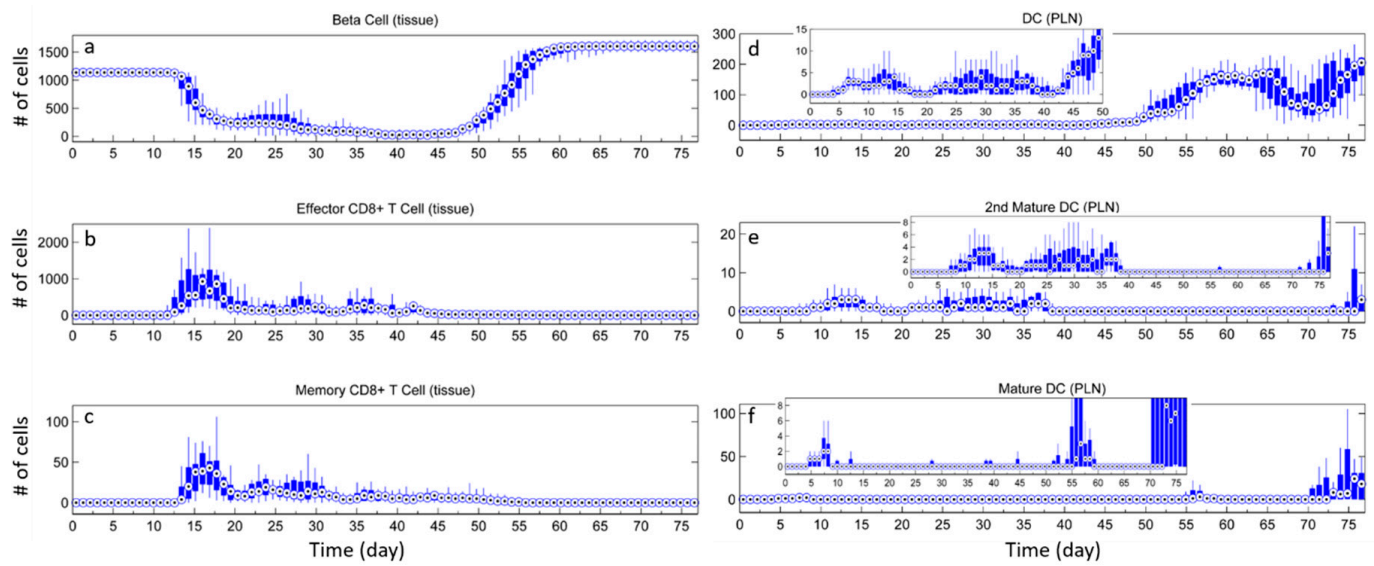

Figure 8. Simulation results for case with Tregs intervention (case VI). There are no initial Tregs and also no conversion ability of $\mathrm{CD}^{+} \mathrm{T}$ cells. Tregs were added at 8 th week. The number of (a) $\beta$ cells, (b) effector $\mathrm{CD}^{+} \mathrm{T}$ cells, (c) memory $\mathrm{CD}^{+} \mathrm{T}$ cells- in pancreatic tissue are shown on the left column. The number of (d) total DCs, (e) 2nd mature DCs, (f) mature DCs in PLN are shown on the right column. Inserts (number of cells vs. time) show small change of cell number in the bottom figures. $\mathrm{t}=0$ days correspond to 3 -week age of mouse. 

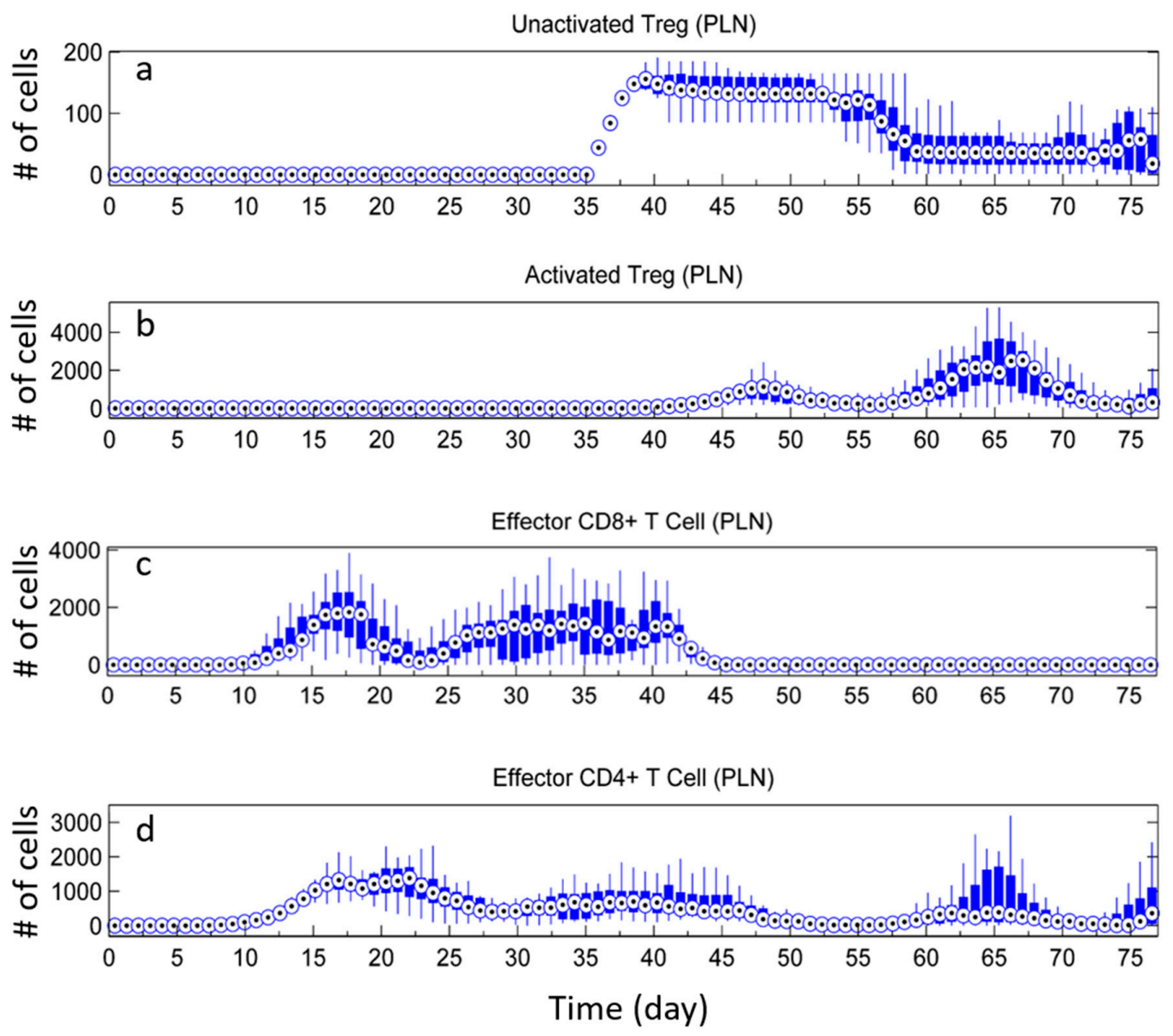

Figure 9. Simulation results for case with Tregs intervention (case VI). Tregs were added at 8th week. The number of (a) unactivated Tregs, (b) activated Tregs, (c) effector CD8 ${ }^{+} \mathrm{T}$ cells, (d) effector CD4 ${ }^{+} \mathrm{T}$ cells in PLN are shown. $t=0$ days correspond to 3-week age of mouse.

\section{Discussion}

This work simulates immune response in mice from 3-weeks old to 14-weeks old. DCs and macrophages can be observed early in pancreatic tissue at 3-week old mice [63] and T cells can be observed at 4th week [30]. Here the effector $\mathrm{CD}^{+} \mathrm{T}$ cells arise in pancreatic tissue approximately 10 days after beginning of the simulation (week 3) (Figures 4 and 8), using about one week for presenting antigen, expansion and migration. In experiments, Treg-deficiency can lead to much more $\mathrm{CD}^{+} \mathrm{T}$ cell proliferation [64] and variations in the ratio of Tregs to $\mathrm{CD} 8^{+} \mathrm{T}$ cells can suppress $\mathrm{T}$ cell proliferation in different degrees [3]. For our model, in the case without Tregs (Section 3.1), the effector $\mathrm{CD}^{+} \mathrm{T}$ cells can increase to $2000 \sim 4000$ cells (Figure 5f) and CD8 ${ }^{+} \mathrm{T}$ cells can reach to 2000 in lymph node (Figure $5 \mathrm{~b}$ ), while they are reduced in the case with Tregs (Section 3.2) to 500 1500 for CD4 ${ }^{+} \mathrm{T}$ cells and $0 \sim 20$ for $\mathrm{CD}^{+} \mathrm{T}$ cells in PLN (Figure 7f,b). The results suggest that Tregs partially inhibit effector $\mathrm{CD} 4^{+} \mathrm{T}$ cell production and largely inhibit effector $\mathrm{CD} 8^{+} \mathrm{T}$ cell proliferation, relatively matching with experiment results.

In the case without induced Tregs, the cell behavior and number variations are similar to the case with Tregs and there is no $\beta$ cell damage and T cells are inhibited (Figures A1 and A2). When there are only induced Tregs (Figures A3 and A4), they cannot inhibit T cell expansion in the former phase, however, they gradually inhibit destructive $\mathrm{T}$ cells in later phase with increase of Tregs. Compared to the case with external addition of Tregs (Section 3.4), they cannot effectively prevent $\beta$ cell damage (Figure A3) by $\mathrm{T}$ cells at the beginning of apparent Treg increase (day 15 40) (Figure A4e,f). The first peak of activated Treg number after day 45 is $\sim 700$ (Figure A4f) while in Section 3.4 the peak reaches to 
$\sim 1200$ cells (Figure 9b). This may be caused by the number deficiency in Tregs without activation at the time they were activated.

In Section 3.4, after the Tregs were added to the system, they inhibit 2nd mature DCs production (Figure 8e) and effectively prevent the increase in $\mathrm{CD} 8^{+} \mathrm{T}$ cells (Figure 9c). This work did not consider the effect of tertiary lymphoid organ (TLO), which can recruit and activate naive T cells in inflammatory tissue [65]. Although the experiment by Lee et al. [65] shows it can replace PLN to induce disease after 16 weeks, the naive $T$ cells appear in inflammatory tissue far earlier than this time [30]. The Tregs intervention can effectively prevent effector T cells produced in PLN, but its effect on this structure was not determined.

When Tregs function that downregulate the expression of costimulatory molecules CD80/86 on DCs (case V, Figures A5 and A6) is blocked, the $\beta$ cell damage by $\mathrm{CD}^{+} \mathrm{T}$ cells cannot be effectively inhibited. In this work, $\beta$ cells can recover quickly to maintain intact islets because the rules of regeneration rate chosen here is relatively high (recovery within two weeks). Although there are 2nd wave of effector $\mathrm{CD} 8^{+} \mathrm{T}$ cells, they did not significantly reduce the number of $\beta$ cells. The large increase in DCs induce a large increase in Tregs. Although these Tregs cannot downregulate costimulatory molecules on DCs, it seems that the occupation of DC neighbor space effectively separate DCs and $\mathrm{CD} 8 / 4^{+} \mathrm{T}$ cells.

The $\alpha$ cells can convert to $\beta$ cells $[29,66,67]$, and since they are not targeted by T cells, they provide $\beta$ cells a good source for regeneration. Even in the case without Tregs, they continuously convert to $\beta$ cells. However, the consecutive generated $\beta$ cells lead to the long-term existence of effector T cells in inflammatory tissue. And these effector T cells prevent more neogenic $\beta$ generation. In case VI, with the help of Tregs, $\beta$ cell population can go back to its initial number by high-speed regeneration. Induction of conversion from $\alpha$ cell to $\beta$ cell and promotion of $\beta$ regeneration could be a good treatment for T1D. Considering that neogenic $\beta$ cell may lead to more lymphocytes, Tregs can inhibit antigen presentation by DCs to some extent and provide a better environment for islet recovery (neogenesis of $\beta$ cell and BM reconstruction). Therefore, considering the treatment of this disease, combining Tregs intervention and promotion of $\beta$ cell regeneration may be a good way to recover healthy islet function.

The pathogenesis of T1D is very complex. It involves many kinds of lymphocytes and antigen presenting cells. This work only focused on DC-CD8 ${ }^{+} \mathrm{T}$ cell pathway in immune response. B cellscan also stimulate $\mathrm{CD}^{+} \mathrm{T}$ cells and activate $\mathrm{CD} 8^{+} \mathrm{T}$ cells with expression of $\mathrm{CD} 40$. Macrophages can present antigen, help to recruit DCs, and secrete molecules to kill $\beta$ cells. There are several pathways (DC/B-CD8 ${ }^{+} \mathrm{T}$ cell, CD/B-CD4 ${ }^{+} \mathrm{T}$ cell, and macrophage pathway) to kill $\beta$ cells. They are cross-linked and the study of each pathway is necessary. In the future, the other pathway to kill $\beta$ cells and their regulation would be implemented, such as B cells and their regulation, more functions of Tregs, and other functions of $\mathrm{CD} 4^{+} \mathrm{T}$ cells with/without macrophages.

\section{Conclusions}

An ABM is developed for simulating different cell interactions during the potential periods of disease progression in T1D. The Tregs that exist in the immune system can regulate the number and function of effector T cells. $\alpha$ cells could be a good source for $\beta$ cell regeneration. Tregs intervention shows effective prevention of new waves of effector $\mathrm{T}$ cells which bring a good environment for $\beta$ cell recovery in treatment of disease. Simulations with various conditions can provide insight about potential treatments can may be more promising in slowing $\beta$ cell death and promote $\beta$ cell regeneration.

Author Contributions: All authors contributed to the initial design and subsequent development of the model. Q.X. developed code to run simulations and analyzed results from them. M.C.O. provided support for code validation. All authors drafted, edited the manuscript.

Funding: This research was funded by National Science Foundation [IIS-1125412].

Acknowledgments: This research is partially supported by National Science Foundation (IIS-1125412). 
Conflicts of Interest: The authors declare no conflict of interest.

\section{Appendix A}
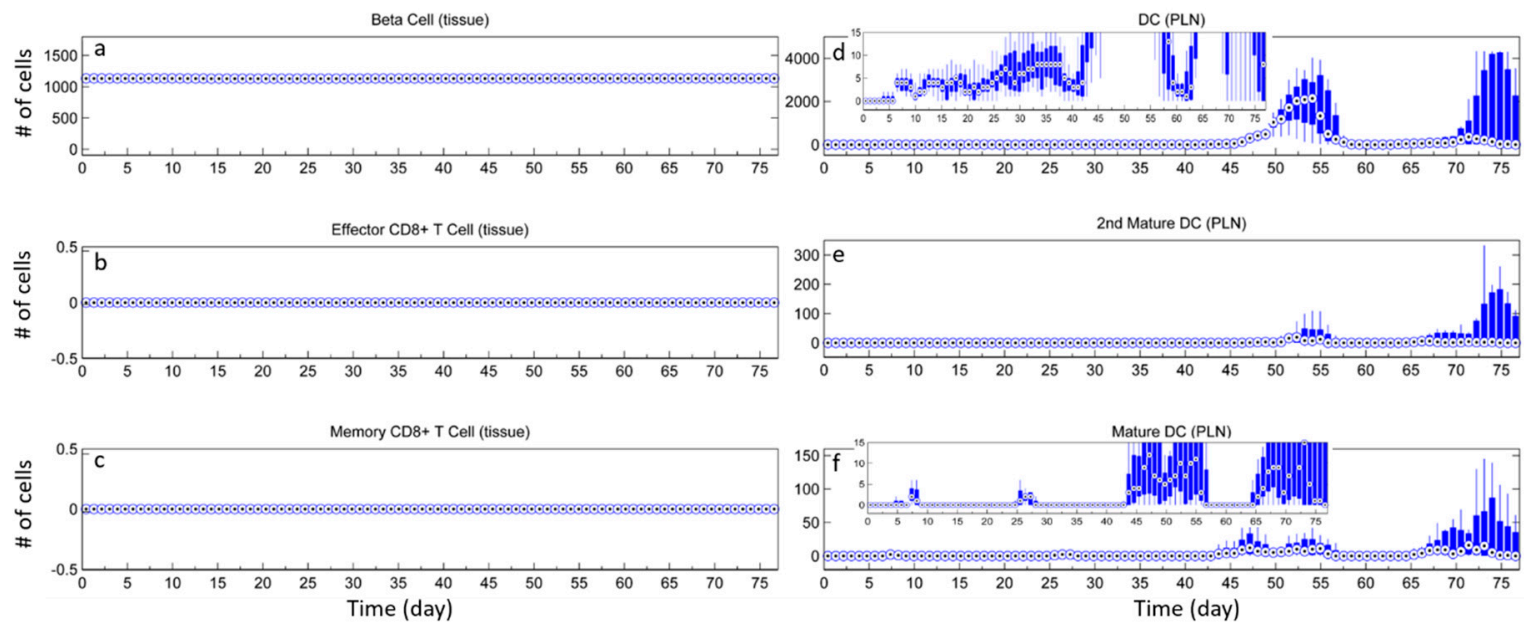

Figure A1. Simulation results for case with initial Tregs (case III). There are initial Tregs but no conversion ability of $\mathrm{CD} 4^{+} \mathrm{T}$ cells. The number of (a) $\beta$ cells, (b) effector CD8 ${ }^{+} \mathrm{T}$ cells, (c) memory $\mathrm{CD}^{+} \mathrm{T}$ cells- in pancreatic tissue are shown on the left column. The number of (d) total DCs, (e) 2nd mature DCs, (f) mature DCs in PLN are shown on the right column. Inserts (number of cells vs. time) show small change of cell number in the bottom figures. $t=0$ days correspond to 3-week age of mouse.
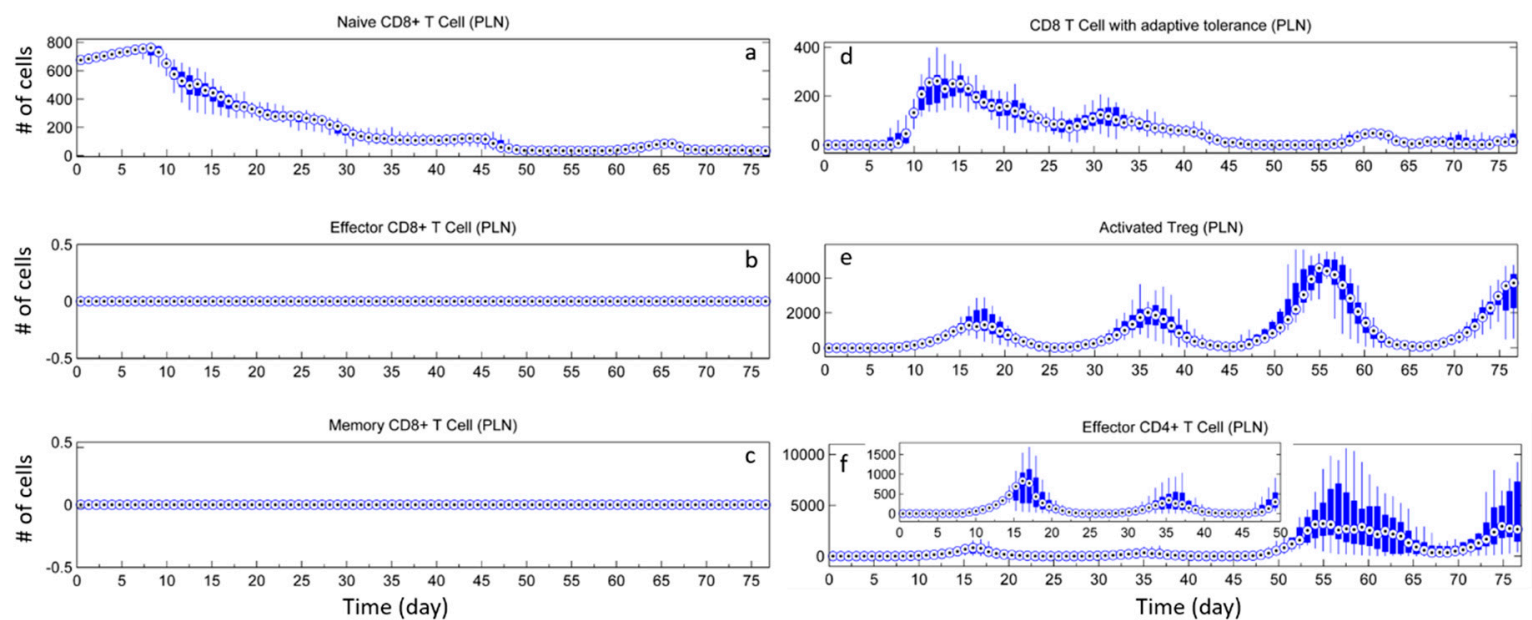

Figure A2. Simulation results for case with initial Tregs (case III). There are initial Tregs but no conversion ability of $\mathrm{CD} 4^{+} \mathrm{T}$ cells. The number of (a) naive $\mathrm{CD} 8^{+} \mathrm{T}$ cells, (b) effector $\mathrm{CD} 8^{+} \mathrm{T}$ cells, (c) memory $\mathrm{CD}^{+} \mathrm{T}$ cells, (d) $\mathrm{CD}^{+} \mathrm{T}$ cells with adaptive tolerance, (e) activated Tregs, (f) effector CD4 ${ }^{+}$ T cells in PLN are shown. Inserts (number of cells vs. time) show small change of cell number in the bottom figures. $t=0$ days correspond to 3 -week age of mouse. 

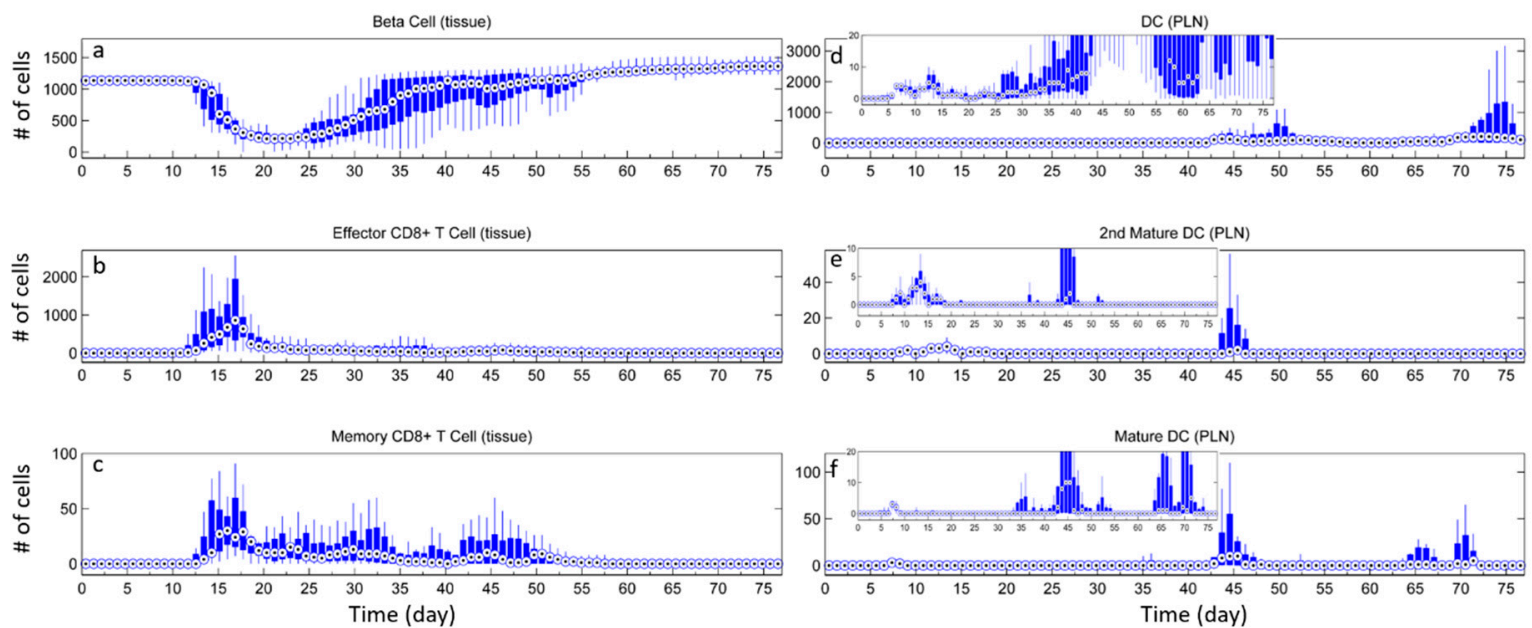

Figure A3. Simulation results for case with induced Tregs (case IV). There are no initial Tregs but conversion ability of $\mathrm{CD}^{+} \mathrm{T}$ cells. The number of (a) $\beta$ cells, (b) effector CD8 ${ }^{+} \mathrm{T}$ cells, (c) memory $\mathrm{CD}^{+} \mathrm{T}$ cells- in pancreatic tissue are shown on the left column. The number of (d) total DCs, (e) 2nd mature DCs, (f) mature DCs in PLN are shown on the right column. Inserts (number of cells vs. time) show small change of cell number in the bottom figures. $t=0$ days correspond to 3-week age of mouse.
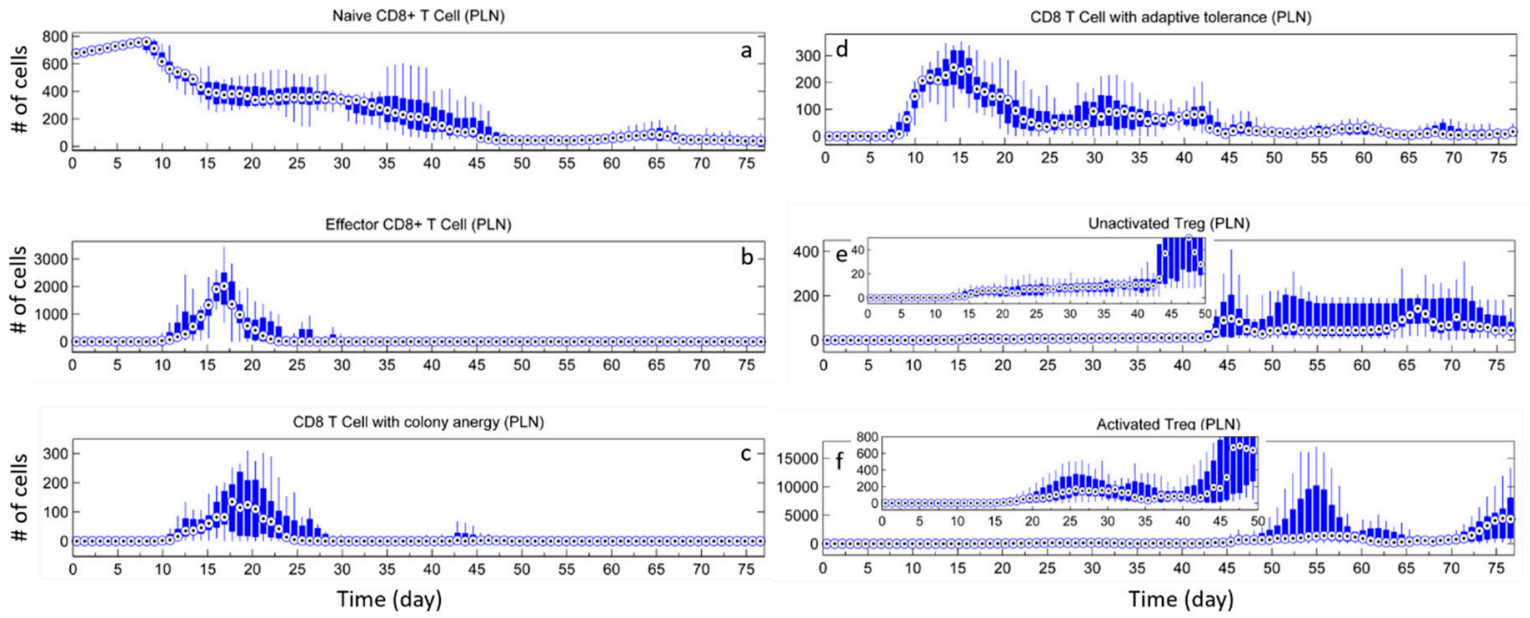

Figure A4. Simulation results for case with induced Tregs (case IV). There are no initial Tregs but conversion ability of $\mathrm{CD} 4^{+} \mathrm{T}$ cells. The number of $(\mathbf{a})$ naive $\mathrm{CD} 8^{+} \mathrm{T}$ cells, (b) effector $\mathrm{CD} 8^{+} \mathrm{T}$ cells, (c) $\mathrm{CD}^{+} \mathrm{T}$ cells with colony anergy, (d) $\mathrm{CD}^{+} \mathrm{T}$ cells with adaptive tolerance, (e) unactivated Tregs, (f) activated Tregs in PLN are shown. Inserts (number of cells vs. time) show small change of cell number in the bottom figures. $t=0$ days correspond to 3 -week age of mouse. 

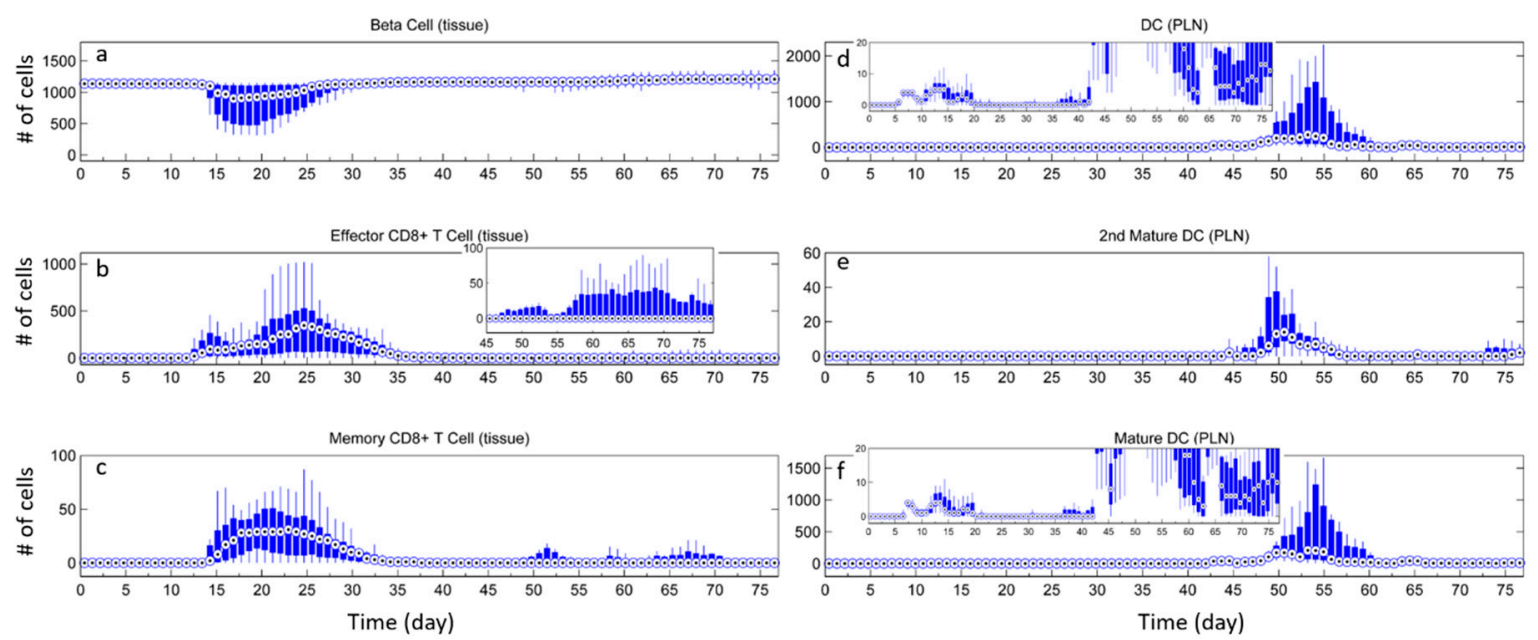

Figure A5. Simulation results for case without inhibiting DCs (case V). Tregs cannot inhibit DCs but can directly inhibit $\mathrm{T}$ cells. The number of $(\mathbf{a}) \beta$ cells, $(\mathbf{b})$ effector $\mathrm{CD} 8^{+} \mathrm{T}$ cells, (c) memory CD8 ${ }^{+} \mathrm{T}$ cells- in pancreatic tissue are shown on the left column. The number of (d) total DCs, (e) 2nd mature DCs, (f) mature DCs in PLN are shown on the right column. Inserts (number of cells vs. time) show small change of cell number in the bottom figures. $t=0$ days correspond to 3 -week age of mouse.
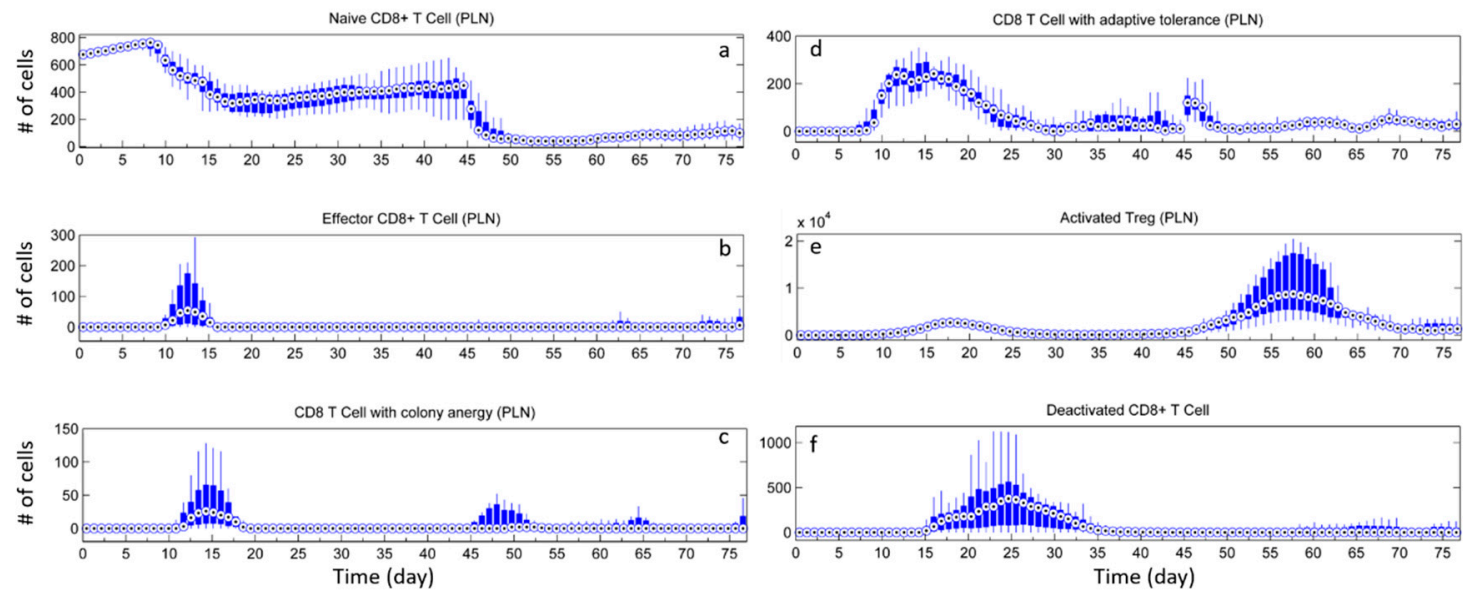

Figure A6. Simulation results for case without inhibiting DCs (case V). Tregs cannot inhibit DCs but can directly inhibit $\mathrm{T}$ cells. The number of (a) naive $\mathrm{CD}^{+} \mathrm{T}$ cells, (b) effector $\mathrm{CD} 8^{+} \mathrm{T}$ cells, (c) $\mathrm{CD} 8^{+} \mathrm{T}$ cells with colony anergy, (d) $\mathrm{CD}^{+} \mathrm{T}$ cells with adaptive tolerance, (e) activated Tregs in PLN and the number of (f) deactivated $\mathrm{CD} 8^{+} \mathrm{T}$ cells in pancreatic tissue are shown. $\mathrm{t}=0$ days correspond to 3-week age of mouse.

\section{References}

1. ElEssawy, B.; Li, X.C. Type 1 diabetes and T regulatory cells. Pharmacol. Res. 2015, 98, 22-30. [CrossRef] [PubMed]

2. Morel, P.A. Dendritic cell subsets in type 1 diabetes: Friend or foe? Front. Immunol. 2013, 4, 415. [CrossRef] [PubMed]

3. Piccirillo, C.A.; Shevach, E.M. Cutting edge: Control of $\mathrm{CD}^{+} \mathrm{T}$ cell activation by CD4 ${ }^{+} \mathrm{CD}^{+} 5^{+}$ immunoregulatory cells. J. Immunol. 2001, 167, 1137-1140. [CrossRef] [PubMed]

4. Waid, D.M.; Vaitaitis, G.M.; Pennock, N.D.; Wagner, D.H., Jr. Disruption of the homeostatic balance between autoaggressive $\left(\mathrm{CD} 4{ }^{+} \mathrm{CD} 40^{+}\right)$and regulatory $\left(\mathrm{CD}^{+} \mathrm{CD} 25^{+}\right.$FoxP3 $\left.^{+}\right) \mathrm{T}$ cells promotes diabetes. J. Leukoc. Biol. 2008, 84, 431-439. [CrossRef] [PubMed] 
5. Bluestone, J.A.; Buckner, J.H.; Fitch, M.; Gitelman, S.E.; Gupta, S.; Hellerstein, M.K.; Herold, K.C.; Lares, A.; Lee, M.R.; Li, K.; et al. Type 1 diabetes immunotherapy using polyclonal regulatory T cells. Sci. Transl. Med. 2015, 7, 315ra189. [CrossRef] [PubMed]

6. Zhao, Y.; Lin, B.; Darflinger, R.; Zhang, Y.; Holterman, M.J.; Skidgel, R.A. Human cord blood stem cell-modulated regulatory $\mathrm{T}$ lymphocytes reverse the autoimmune-caused type 1 diabetes in nonobese diabetic (NOD) mice. PLoS ONE 2009, 4, e4226. [CrossRef] [PubMed]

7. Roncarolo, M.-G.; Battaglia, M. Regulatory T-cell immunotherapy for tolerance to self antigens and alloantigens in humans. Nat. Rev. Immunol. 2007, 7, 585-598. [CrossRef] [PubMed]

8. The Mount Hood 4 Group. Computer modeling of diabetes and its complications. Diabetes Care 2007, 30, 1638-1646. [CrossRef] [PubMed]

9. Balakrishnan, N.P.; Rangaiah, G.P.; Samavedham, L. Review and analysis of blood glucose (BG) models for type 1 diabetic patients. Ind. Eng. Chem. Res. 2011, 50, 12041-12066. [CrossRef]

10. Henriksson, M.; Jindal, R.; Sternhufvud, C.; Bergenheim, K.; Sorstadius, E.; Willis, M. A systematic review of cost-effectiveness models in type 1 diabetes mellitus. Pharmacoeconomics 2016, 34, 569-585. [CrossRef] [PubMed]

11. Makroglou, A.; Li, J.; Kuang, Y. Mathematical models and software tools for the glucose-insulin regulatory system and diabetes: An overview. Appl. Numer. Math. 2006, 56, 559-573. [CrossRef]

12. Shoda, L.; Kreuwel, H.; Gadkar, K.; Zheng, Y.; Whiting, C.; Atkinson, M.; Bluestone, J.; Mathis, D.; Young, D.; Ramanujan, S. The type 1 diabetes physiolab ${ }^{\circledR}$ platform: A validated physiologically based mathematical model of pathogenesis in the non-obese diabetic mouse. Clin. Exp. Immunol. 2010, 161, 250-267. [CrossRef] [PubMed]

13. Martínez, I.V.; Hernando, M.E.; Gómez, E.J.; Villares, R.; Mellado, M. Definition of an agent-based model of the autoimmune response in type 1 diabetes. In Proceedings of the 7 th Iberian Conference on Information Systems and Technologies (CISTI 2012), Madrid, Spain, 20-23 June 2012; pp. 1-4.

14. Wedgwood, K.C.; Richardson, S.J.; Morgan, N.G.; Tsaneva-Atanasova, K. Spatiotemporal dynamics of insulitis in human type 1 diabetes. Front. Physiol. 2016, 7, 633. [CrossRef] [PubMed]

15. Bonabeau, E. Agent-based modeling: Methods and techniques for simulating human systems. Proc. Natl. Acad. Sci. USA 2002, 99, 7280-7287. [CrossRef] [PubMed]

16. Ozturk, M.C.; Xu, Q.; Cinar, A. Agent-based modeling of the interaction between $\mathrm{CD} 8^{+} \mathrm{T}$ cells and beta cells in type 1 diabetes. PLoS ONE 2018, 13, e0190349. [CrossRef] [PubMed]

17. Collier, N.; North, M. Repast HPC: A platform for large-scale agent-based modeling. In Large-Scale Computing; Dubitzky, W., Kurowski, K., Schott, B., Eds.; John Wiley \& Sons, Inc.: New York, NY, USA, 2012.

18. Zhang, X.; Giangreco, L.; Broome, H.E.; Dargan, C.M.; Swain, S.L. Control of CD4 effector fate: Transforming growth factor beta 1 and interleukin 2 synergize to prevent apoptosis and promote effector expansion. J. Exp. Med. 1995, 182, 699-709. [CrossRef] [PubMed]

19. Den Braber, I.; Mugwagwa, T.; Vrisekoop, N.; Westera, L.; Mogling, R.; de Boer, A.B.; Willems, N.; Schrijver, E.H.; Spierenburg, G.; Gaiser, K.; et al. Maintenance of peripheral naive T cells is sustained by thymus output in mice but not humans. Immunity 2012, 36, 288-297. [CrossRef] [PubMed]

20. Matheu, M.P.; Othy, S.; Greenberg, M.L.; Dong, T.X.; Schuijs, M.; Deswarte, K.; Hammad, H.; Lambrecht, B.N.; Parker, I.; Cahalan, M.D. Imaging regulatory T cell dynamics and CTLA4-mediated suppression of T cell priming. Nat. Commun. 2015, 6, 6219. [CrossRef] [PubMed]

21. Schmitz, I.; Krueger, A.; Baumann, S.; Schulze-Bergkamen, H.; Krammer, P.H.; Kirchhoff, S. An IL-2-dependent switch between CD95 signaling pathways sensitizes primary human T cells toward CD95-mediated activation-induced cell death. J. Immunol. 2003, 171, 2930-2936. [CrossRef] [PubMed]

22. Coppieters, K.; Amirian, N.; von Herrath, M. Intravital imaging of CTLs killing islet cells in diabetic mice. J. Clin. Investig. 2012, 122, 119-131. [CrossRef] [PubMed]

23. Kinjyo, I.; Qin, J.; Tan, S.Y.; Wellard, C.J.; Mrass, P.; Ritchie, W.; Doi, A.; Cavanagh, L.L.; Tomura, M.; Sakaue-Sawano, A.; et al. Real-time tracking of cell cycle progression during $\mathrm{CD}^{+}$effector and memory T-cell differentiation. Nat. Commun. 2015, 6, 6301. [CrossRef] [PubMed]

24. Bousso, P. T-cell activation by dendritic cells in the lymph node: Lessons from the movies. Nat. Rev. Immunol. 2008, 8, 675-684. [CrossRef] [PubMed]

25. Kamath, A.T.; Henri, S.; Battye, F.; Tough, D.F.; Shortman, K. Developmental kinetics and lifespan of dendritic cells in mouse lymphoid organs. Blood 2002, 100, 1734-1741. [PubMed] 
26. Coppieters, K.; Martinic, M.M.; Kiosses, W.B.; Amirian, N.; Herrath, M.V. A novel technique for the in vivo imaging of autoimmune diabetes development in the pancreas by two-photon microscopy. PLoS ONE 2010, 5, e15732. [CrossRef] [PubMed]

27. Fisson, S.; Darrasse-Jeze, G.; Litvinova, E.; Septier, F.; Klatzmann, D.; Liblau, R.; Salomon, B.L. Continuous activation of autoreactive $\mathrm{CD} 4^{+} \mathrm{CD} 25^{+}$regulatory T cells in the steady state. J. Exp. Med. 2003, 198, 737-746. [CrossRef] [PubMed]

28. Yamazaki, S.; Iyoda, T.; Tarbell, K.; Olson, K.; Velinzon, K.; Inaba, K.; Steinman, R.M. Direct expansion of functional $\mathrm{CD} 25^{+} \mathrm{CD} 4{ }^{+}$regulatory $\mathrm{T}$ cells by antigen-processing dendritic cells. J. Exp. Med. 2003, 198, 235-247. [CrossRef] [PubMed]

29. Chung, C.H.; Hao, E.; Piran, R.; Keinan, E.; Levine, F. Pancreatic $\beta$-cell neogenesis by direct conversion from mature alpha-cells. Stem Cells 2010, 28, 1630-1638. [CrossRef] [PubMed]

30. Magnuson, A.M.; Thurber, G.M.; Kohler, R.H.; Weissleder, R.; Mathis, D.; Benoist, C. Population dynamics of islet-infiltrating cells in autoimmune diabetes. Proc. Natl. Acad. Sci. USA 2015, 112, 1511-1516. [CrossRef] [PubMed]

31. Chintinne, M.; Stange, G.; Denys, B.; Ling, Z.; Veld, P.I.; Pipeleers, D. Beta cell count instead of beta cell mass to assess and localize growth in beta cell population following pancreatic duct ligation in mice. PLoS ONE 2012, 7, e43959. [CrossRef] [PubMed]

32. Wing, K.; Sakaguchi, S. Regulatory t cells exert checks and balances on self tolerance and autoimmunity. Nat. Immunol. 2010, 11, 7-13. [CrossRef] [PubMed]

33. Wu, J.; Yang, X.; Chen, B.; Xu, X. Pancreas $\beta$ cell regeneration and type 1 diabetes (review). Exp. Ther. Med. 2015, 9, 653-657. [CrossRef] [PubMed]

34. Collombat, P.; Xu, X.; Ravassard, P.; Sosa-Pineda, B.; Dussaud, S.; Billestrup, N.; Madsen, O.D.; Serup, P.; Heimberg, H.; Mansouri, A. The ectopic expression of pax4 in the mouse pancreas converts progenitor cells into $\alpha$ and subsequently $\beta$ cells. Cell 2009, 138, 449-462. [CrossRef] [PubMed]

35. Marcela, B.; Michael, J.F.; Wendell, E.N.; Anita, C.; Boaz, H.; David, M.H.; Alvin, C.P. Assessment of human pancreatic islet architecture and composition by laser scanning confocal microscopy. J. Histochem. Cytochem. 2005, 53, 1087-1097. [CrossRef]

36. Korsgren, E.; Korsgren, O. An apparent deficiency of lymphatic capillaries in the islets of langerhans in the human pancreas. Diabetes 2016, 65, 1004-1008. [CrossRef] [PubMed]

37. Dieu, M.-C.; Vanvervliet, B.; Vicari, A.; Bridon, J.-M.; Oldham, E.; Ait-Yahia, S.; Briere, F.; Zlotnik, A.; Lebecque, S.; Caux, C. Selective recruitment of immature and mature dendritic cells by distinct chemokines expressed in different anatomic sites. J. Exp. Med. 1998, 188, 373-386. [CrossRef] [PubMed]

38. Caux, C.; Vanbervliet, B.; Massacrier, C.; Ait-Yahia, S.; Vaure, C.; Chemin, K.; Dieu-Nosjean, M.-C.; Vicari, A. Regulation of dendritic cell recruitment by chemokines. Transplantation 2002, 73, S7-S11. [CrossRef] [PubMed]

39. Caux, C.; Dubois, B. Antigen uptake by dendritic cells. Methods Mol. Med. 2001, 64, 369-376. [CrossRef] [PubMed]

40. Banchereau, J.; Steinman, R.M. Dendritic cells and the control of immunity. Nature 1998, 392, $245-252$. [CrossRef] [PubMed]

41. Pletinckx, K.; Dohler, A.; Pavlovic, V.; Lutz, M.B. Role of dendritic cell maturity/costimulation for generation, homeostasis, and suppressive activity of regulatory T cells. Front. Immunol. 2011, 2, 39. [CrossRef] [PubMed]

42. Price, J.D.; Tarbell, K.V. The role of dendritic cell subsets and innate immunity in the pathogenesis of type 1 diabetes and other autoimmune diseases. Front. Immunol. 2015, 6, 288. [CrossRef] [PubMed]

43. Regoli, M.; Bertelli, E.; Orazioli, D.; Fonzi, L.; Bastianini, A. Pancreatic lymphatic system in rodents. Anat. Rec. 2011, 263, 155-160. [CrossRef] [PubMed]

44. Randolph, G.J.; Angeli, V.; Swartz, M.A. Dendritic-cell trafficking to lymph nodes through lymphatic vessels. Nat. Rev. Immunol. 2005, 5, 617-628. [CrossRef] [PubMed]

45. Vasilevko, V.; Ghochikyan, A.; Holterman, M.J.; Agadjanyan, M.G. CD80 (B7-1) and CD86 (B7-2) are functionally equivalent in the initiation and maintenance of $\mathrm{CD}^{+} \mathrm{T}$-cell proliferation after activation with suboptimal doses of PHA. DNA Cell Biol. 2002, 21, 137-149. [CrossRef] [PubMed]

46. Schildknecht, A.; Miescher, I.; Yagita, H.; van den Broek, M. Priming of CD8 ${ }^{+} \mathrm{T}$ cell responses by pathogens typically depends on CD70-mediated interactions with dendritic cells. Eur. J. Immunol. 2007, 37, 716-728. [CrossRef] [PubMed] 
47. Onishi, Y.; Fehervari, Z.; Yamaguchi, T.; Sakaguchi, S. Foxp3 ${ }^{+}$natural regulatory T cells preferentially form aggregates on dendritic cells in vitro and actively inhibit their maturation. Proc. Natl. Acad. Sci. USA 2008, 105, 10113-10118. [CrossRef] [PubMed]

48. Taraban, V.Y.; Rowley, T.F.; Al-Shamkhani, A. Cutting edge: A critical role for CD70 in CD8 T cell priming by CD40-licensed APCs. J. Immunol. 2004, 173, 6542-6546. [CrossRef] [PubMed]

49. Sanchez, P.J.; McWilliams, J.A.; Haluszczak, C.; Yagita, H.; Kedl, R.M. Combined TLR/CD40 stimulation mediates potent cellular immunity by regulating dendritic cell expression of CD70 in vivo. J. Immunol. 2007, 178, 1564-1572. [CrossRef] [PubMed]

50. Eizirik, D.L.; Mandrup-Poulsen, T. A choice of death-the signal-transduction of immune-mediated beta-cell apoptosis. Diabetologia 2001, 44, 2115-2133. [CrossRef] [PubMed]

51. Schwartz, R.H. T cell anergy. Annu. Rev. Immunol. 2003, 21, 305-334. [CrossRef] [PubMed]

52. Feau, S.; Garcia, Z.; Arens, R.; Yagita, H.; Borst, J.; Schoenberger, S.P. The CD4 ${ }^{+}$T-cell help signal is transmitted from APC to CD8 ${ }^{+}$T-cells via CD27-CD70 interactions. Nat. Commun. 2012, 3, 948. [CrossRef] [PubMed]

53. Bevan, M.J. Helping the CD8 ${ }^{+}$T-cell response. Nat. Rev. Immunol. 2004, 4, 595-602. [CrossRef] [PubMed]

54. Van Kooten, C.; Banchereau, J. CD40-CD40 ligand. J. Leukoc. Biol. 2000, 67, 2-17. [CrossRef] [PubMed]

55. Davidson, T.S.; DiPaolo, R.J.; Andersson, J.; Shevach, E.M. Cutting edge: IL-2 is essential for TGF- $\beta$-mediated induction of Foxp3 ${ }^{+}$T regulatory cells. J. Immunol. 2007, 178, 4022-4026. [CrossRef] [PubMed]

56. Vignali, D.A.; Collison, L.W.; Workman, C.J. How regulatory T cells work. Nat. Rev. Immunol. 2008, 8, 523-532. [CrossRef] [PubMed]

57. Mempel, T.R.; Pittet, M.J.; Khazaie, K.; Weninger, W.; Weissleder, R.; von Boehmer, H.; von Andrian, U.H. Regulatory $\mathrm{T}$ cells reversibly suppress cytotoxic $\mathrm{T}$ cell function independent of effector differentiation. Immunity 2006, 25, 129-141. [CrossRef] [PubMed]

58. Par, S.; Amrani, A.; Yamanouchi, J.; Han, B.; Thiessen, S.; Utsugi, T.; Verdaguer, J.; Santamaria, P. CD40 ligation releases immature dendritic cells from the control of regulatory $\mathrm{CD} 4{ }^{+} \mathrm{CD} 25^{+} \mathrm{T}$ cells. Immunity 2003, 19, 877-889. [CrossRef]

59. Belkaid, Y. Regulatory T cells and infection: A dangerous necessity. Nat. Rev. Immunol. 2007, 7, 875-888. [CrossRef] [PubMed]

60. Sakaguchi, S.; Yamaguchi, T.; Nomura, T.; Ono, M. Regulatory t cells and immune tolerance. Cell 2008, 133, 775-787. [CrossRef] [PubMed]

61. Roncarolo, M.G.; Gregori, S.; Battaglia, M.; Bacchetta, R.; Fleischhauer, K.; Levings, M.K. Interleukin-10-secreting type 1 regulatory T cells in rodents and humans. Immunol. Rev. 2006, 212, $28-50$. [CrossRef] [PubMed]

62. Burzyn, D.; Benoist, C.; Mathis, D. Regulatory T cells in nonlymphoid tissues. Nat. Immunol. 2013, 14, $1007-1013$. [CrossRef] [PubMed]

63. Bluestone, J.A.; Herold, K.; Eisenbarth, G. Genetics, pathogenesis and clinical interventions in type 1 diabetes. Nature 2010, 464, 1293-1300. [CrossRef] [PubMed]

64. Tang, Q.; Adams, J.Y.; Tooley, A.J.; Bi, M.; Fife, B.T.; Serra, P.; Santamaria, P.; Locksley, R.M.; Krummel, M.F.; Bluestone, J.A. Visualizing regulatory $\mathrm{T}$ cell control of autoimmune responses in nonobese diabetic mice. Nat. Immunol. 2006, 7, 83-92. [CrossRef] [PubMed]

65. Lee, Y.; Chin, R.K.; Christiansen, P.; Sun, Y.; Tumanov, A.V.; Wang, J.; Chervonsky, A.V.; Fu, Y.X. Recruitment and activation of naive $\mathrm{T}$ cells in the islets by lymphotoxin $\beta$ receptor-dependent tertiary lymphoid structure. Immunity 2006, 25, 499-509. [CrossRef] [PubMed]

66. Thorel, F.; Népote, V.; Avril, I.; Kohno, K.; Desgraz, R.; Chera, S.; Herrera, P.L. Conversion of adult pancreatic $\alpha$-cells to $\beta$-cells after extreme $\beta$-cell loss. Nature 2010, 464, 1149-1154. [CrossRef] [PubMed]

67. Zhang, Y.; Fava, G.E.; Wang, H.; Mauvais-Jarvis, F.; Fonseca, V.A.; Wu, H. PAX4 gene transfer induces $\alpha$-to- $\beta$ cell phenotypic conversion and confers therapeutic benefits for diabetes treatment. Mol. Ther. 2016, 24, 251-260. [CrossRef] [PubMed]

(c) 2018 by the authors. Licensee MDPI, Basel, Switzerland. This article is an open access article distributed under the terms and conditions of the Creative Commons Attribution (CC BY) license (http:/ / creativecommons.org/licenses/by/4.0/). 